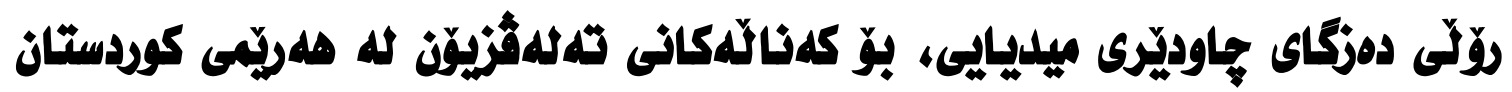

\section{كَاش عاو على فلهرهج}

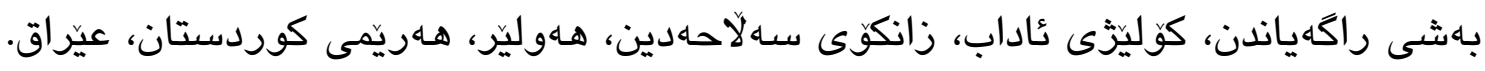
ويمهيل: gashaw.ali.2017@gmail.com

\section{سامان جلالال مdولود}

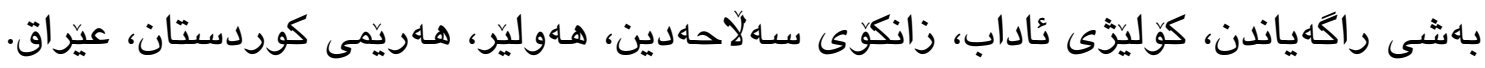
ئيمهيل: gmail.com

צوخته:

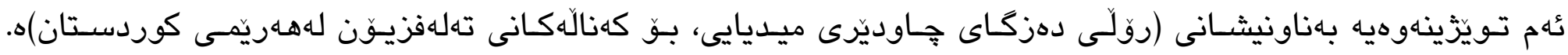

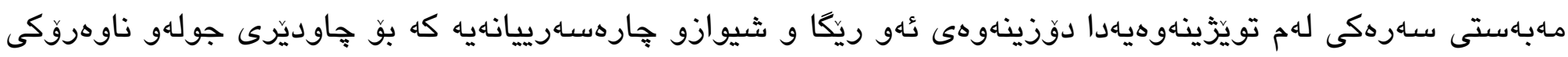

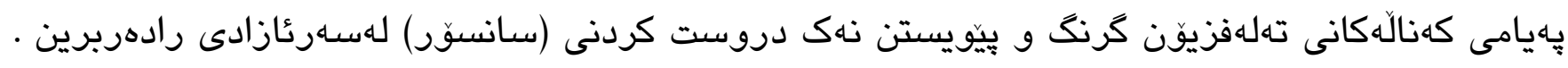

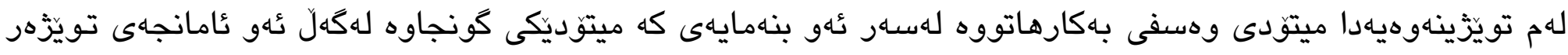

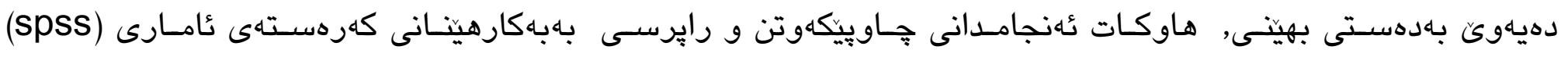

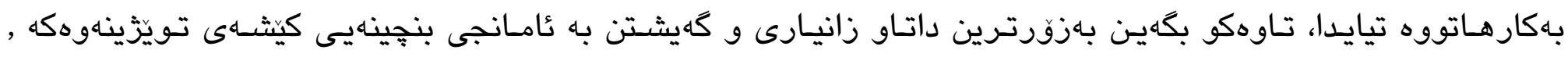

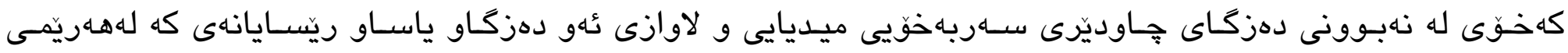

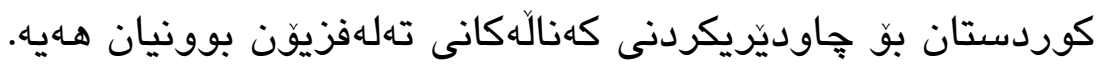

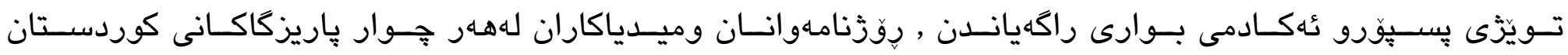

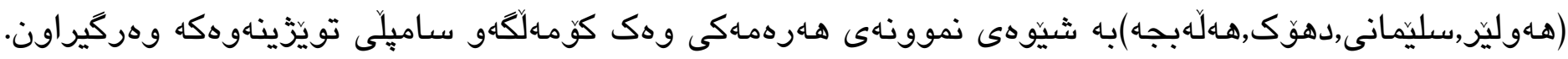

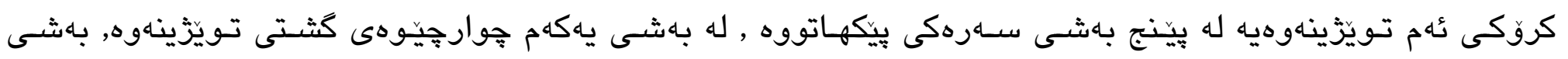

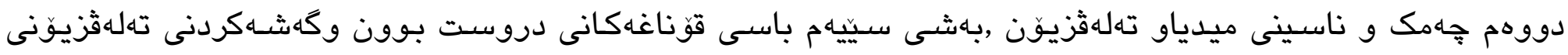

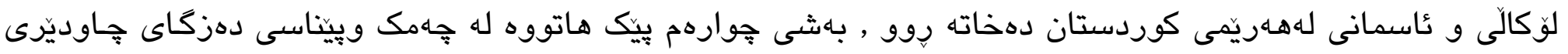




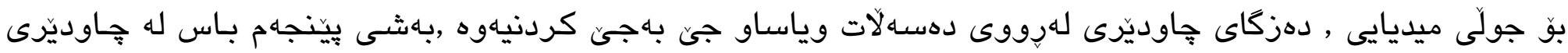
ميديايى له سستمى دهسهلاتدارى جياوازدا دهكات.

سهرئهنجام لهم تويّزينهوهيهدا تويّزهر كَهيشته ئهو راستييهى دهزكاى جاوديرى ميديايى بق هـريّمى كوردستان بهتايبهت

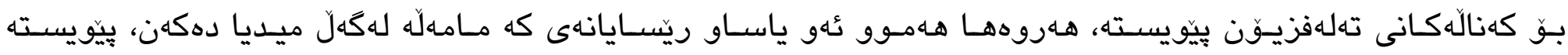

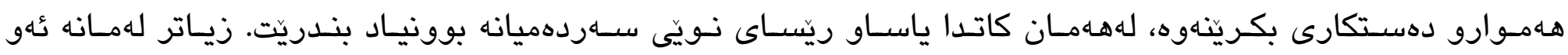

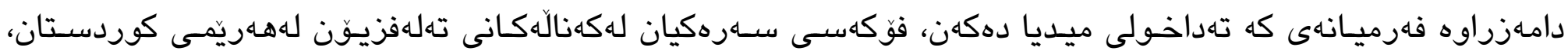

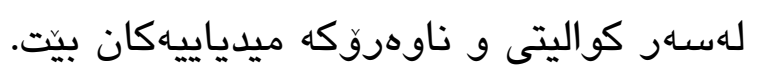

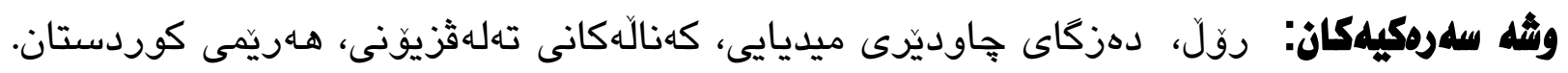

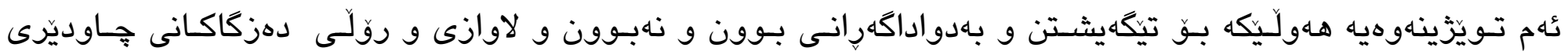

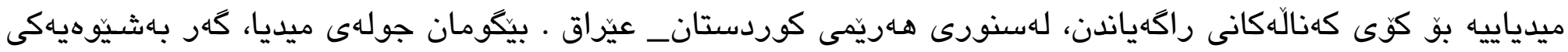

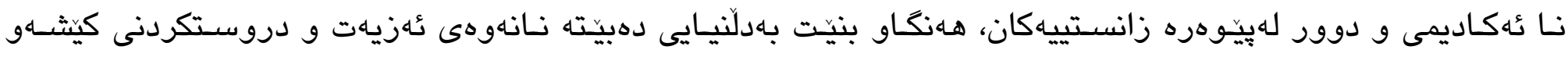

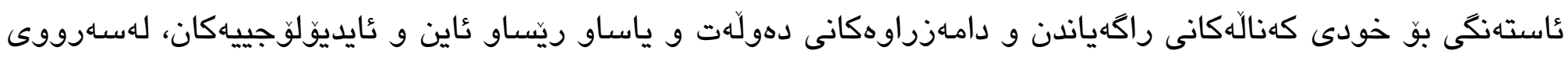

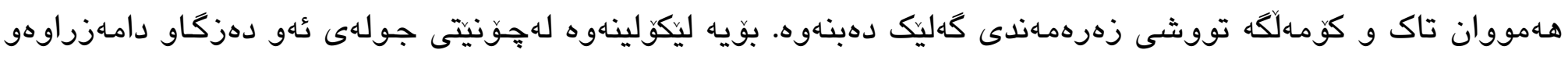

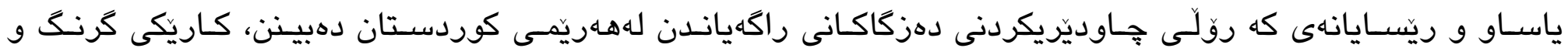

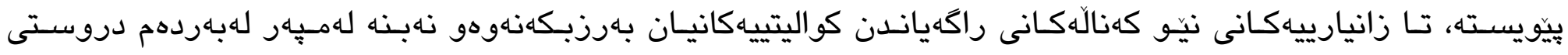

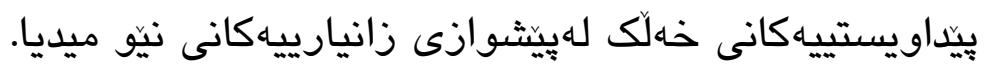

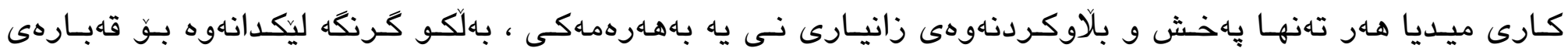

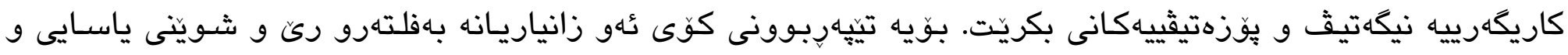

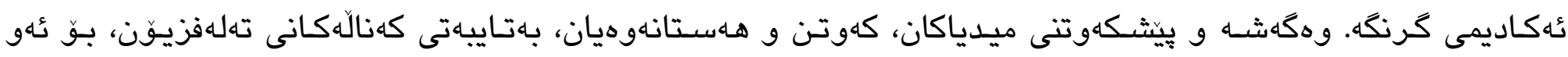

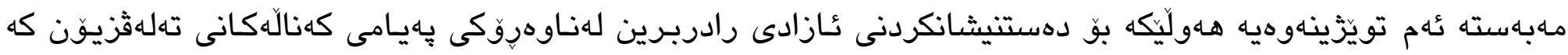

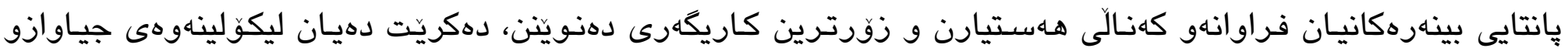

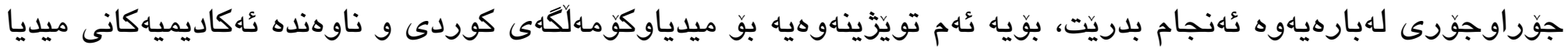
بهايِيّويست زاندرا. 


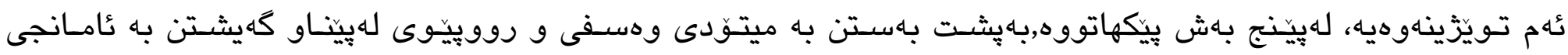

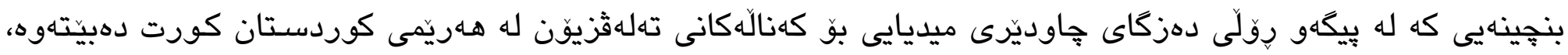

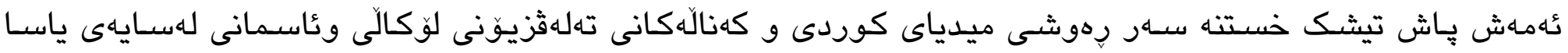

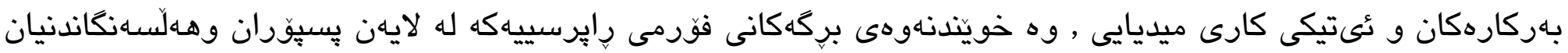

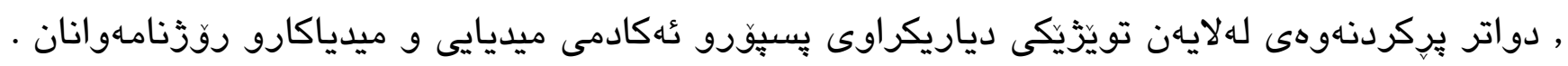

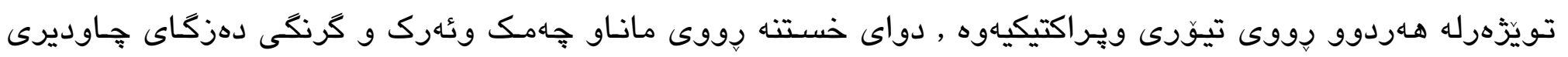

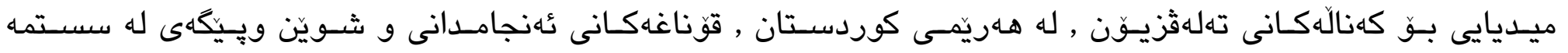

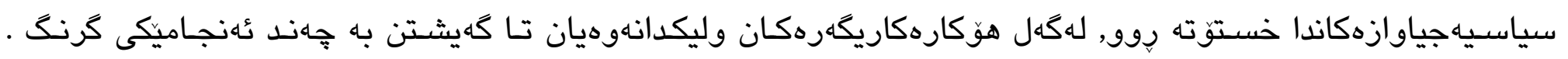

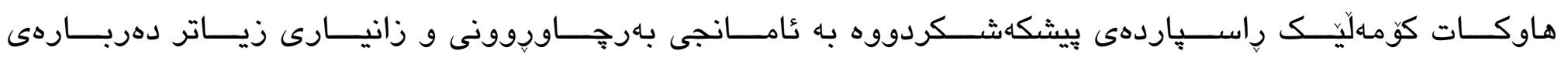
راوبوّجونهجياوازهكان سـهبارهت به بوونى دهزكاى جاوديرى ميديايى و زانينى عاستهنك و لهميهرهكانى بهردهم دروسـت نهبوونى دهزكاى ناوبراو.

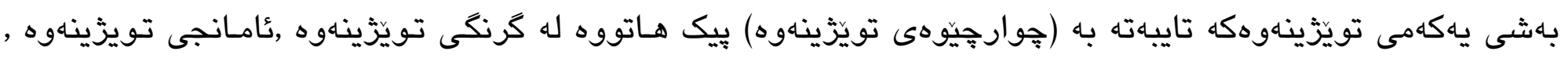

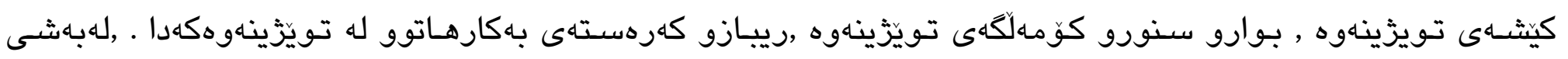

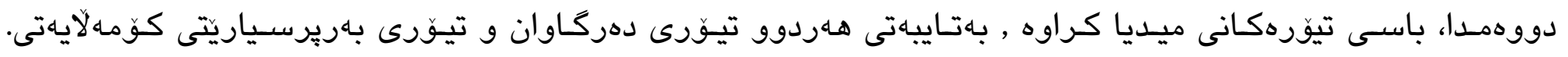

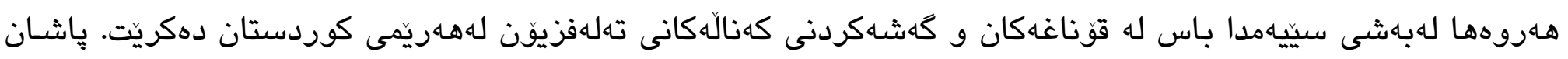

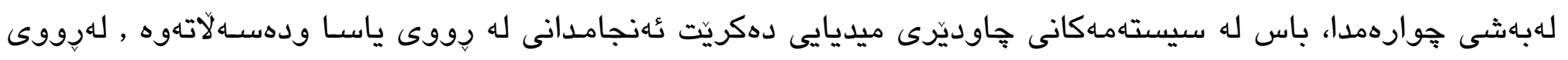

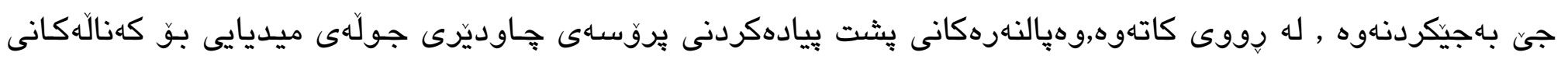

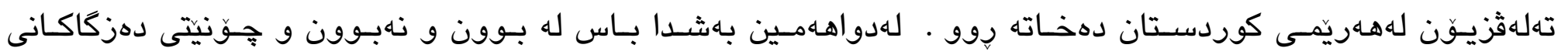

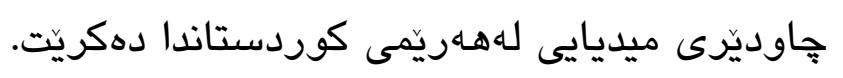

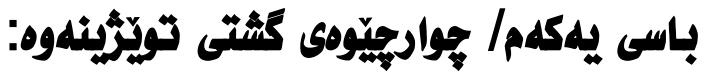

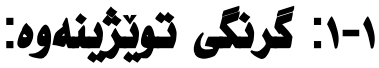

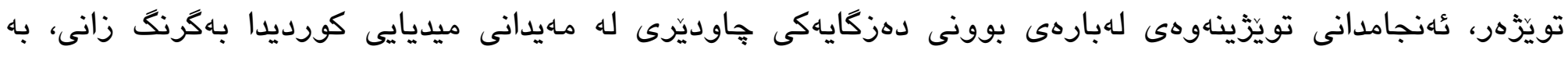

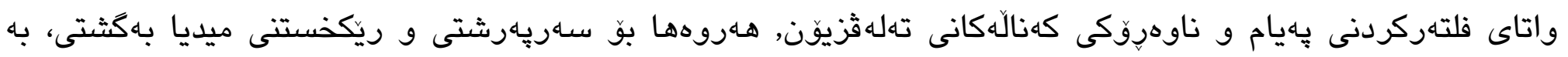

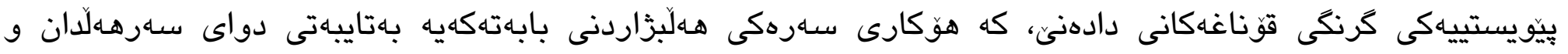
دامـزراندنى زمارهيهكى بحى شومار له كهنالَكانى تهلهثزيوّنى لوَكالَى و دواتر ئاسمانى له كوردستان، دواى فراوان بوونى 


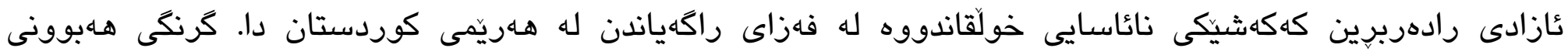

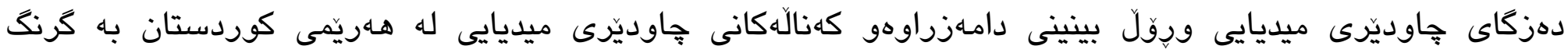

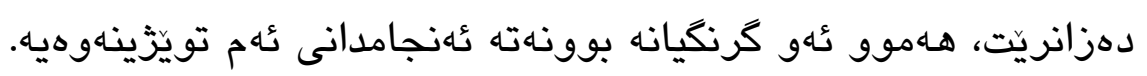

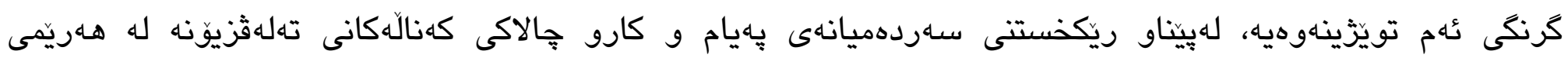

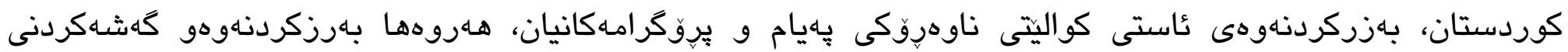

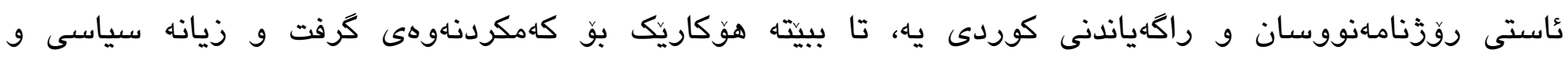

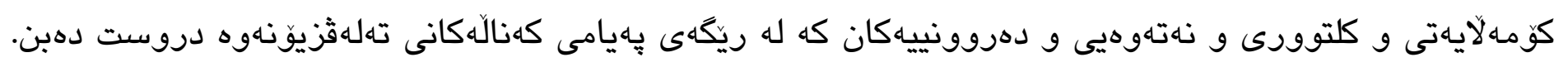

\section{1}

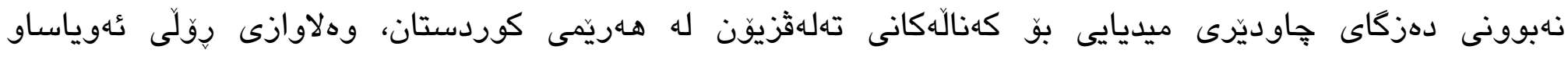

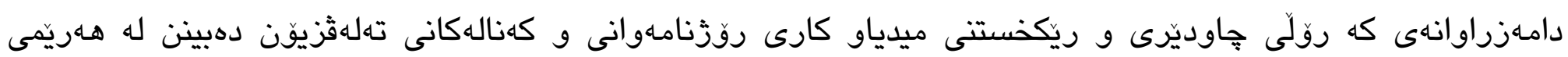
كوردستان.

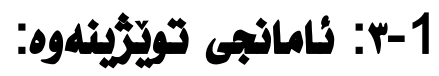

تويزّينهوهى زاستى له ئهمرِّدا، ((بهرهو تايبهتمهندبوون و جارهسـاركردنى وردهكارى هـهنكاو دهنيت، تيشك دهخاته سهار

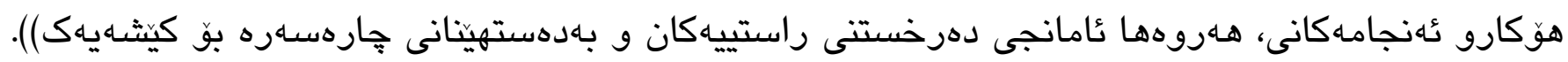
عامانجى تويزّينهوه خُوى دهبينيتهوه له:

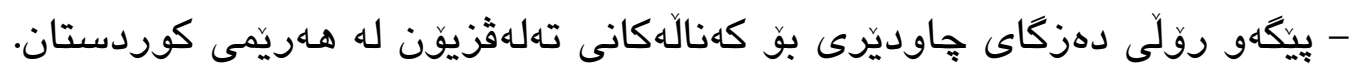

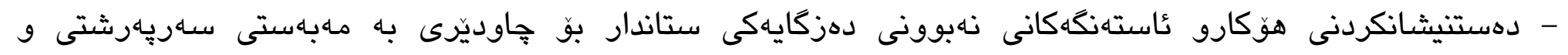

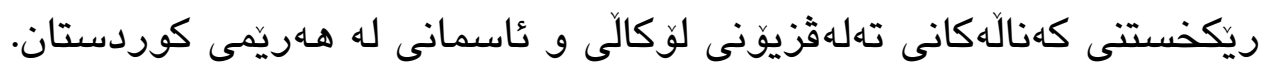

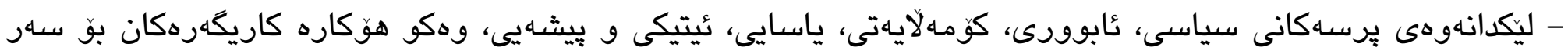
ميدياى كوردى. - مئ.

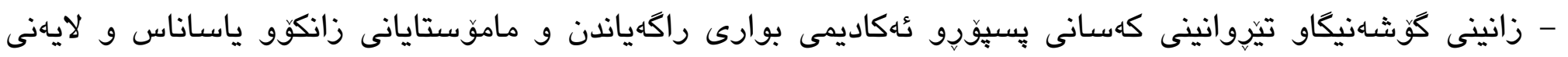

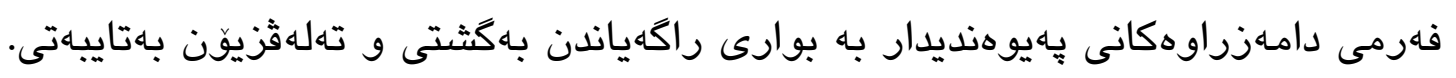

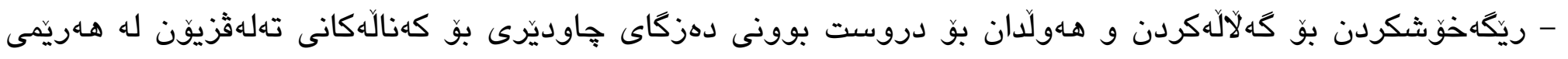

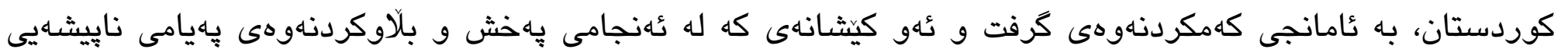

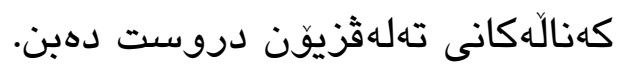


- ريكخستنى دامهزراوهو كهنالَكانى تهله ثزيوّن له هـريّمى كوردستان بهشيّوهيهكى سهردهميانهو هاوجههرخ كه كونجاو

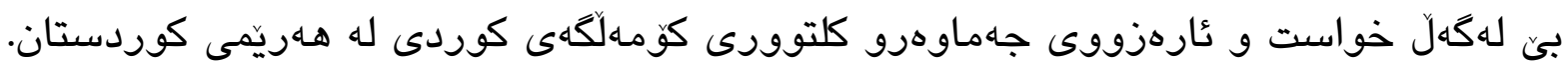

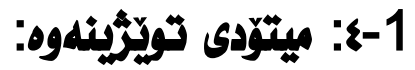

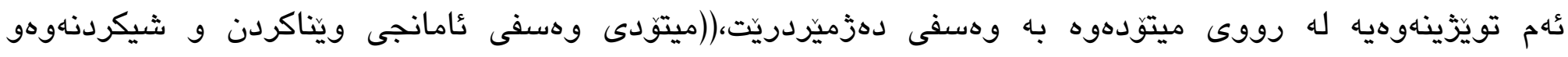

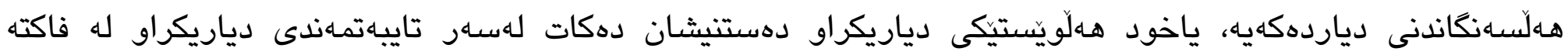

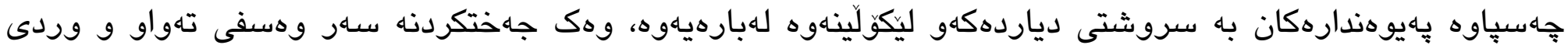

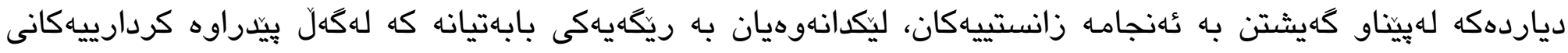

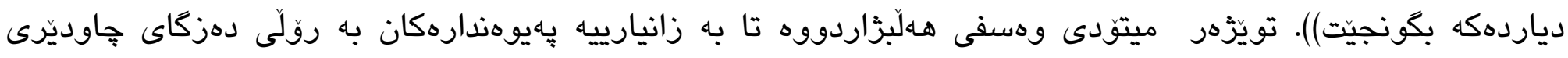

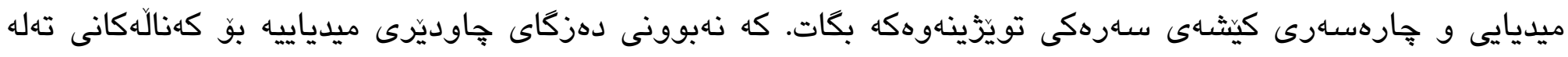

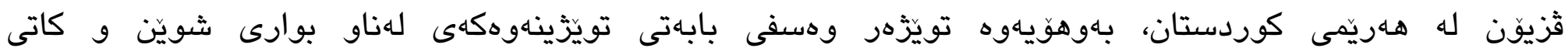
تويزّينهوهكهدا كردووه.

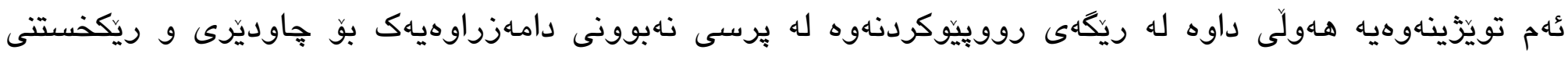

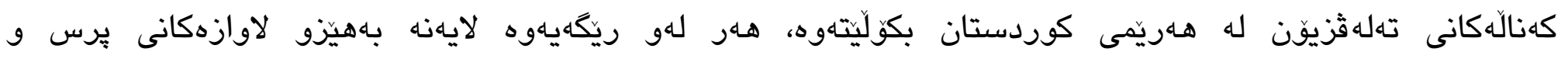

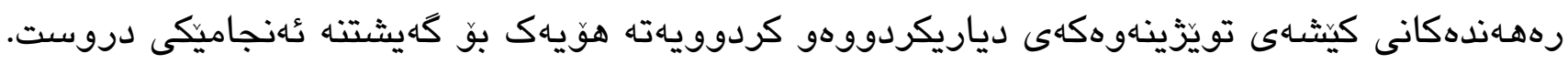

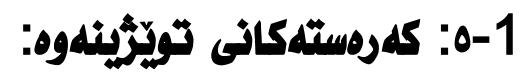

ئهو ريكَّو عامرازانهى له تويَّينهوهكهدا بهكارهاتووه بريتين له:

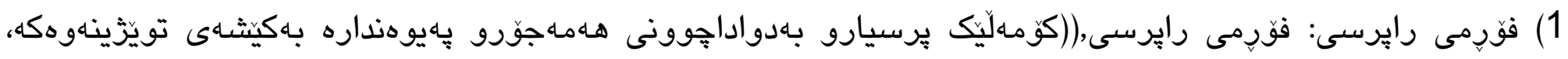

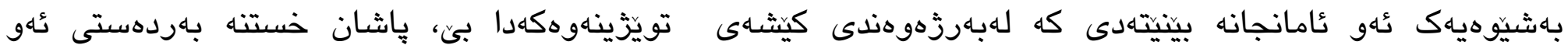

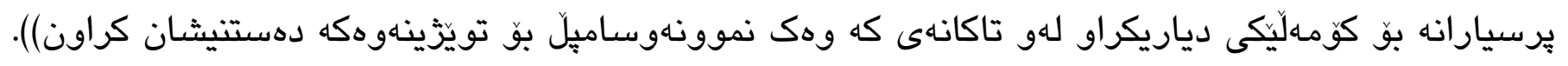

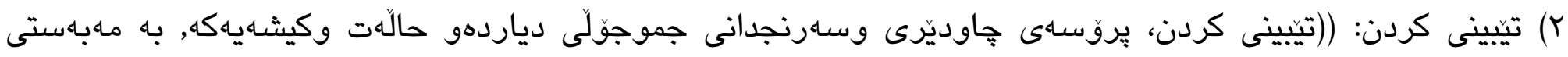

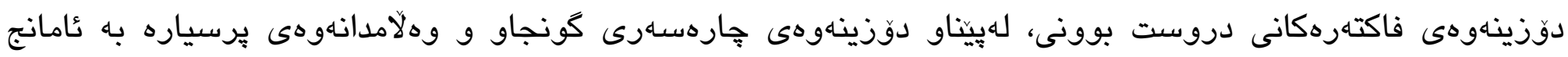

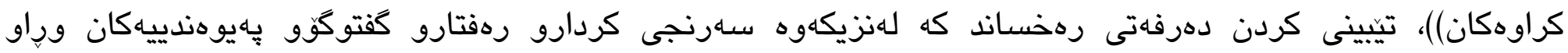

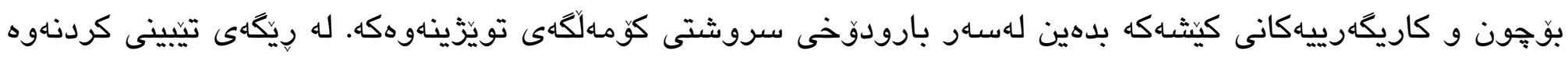

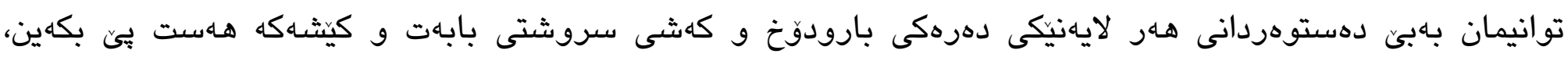

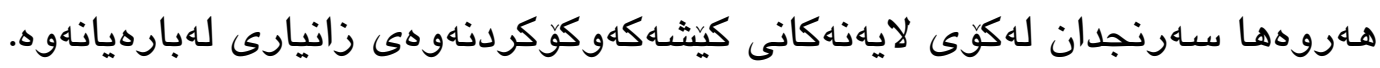
3) جاوينيكهوتن 


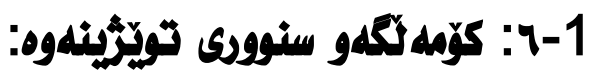

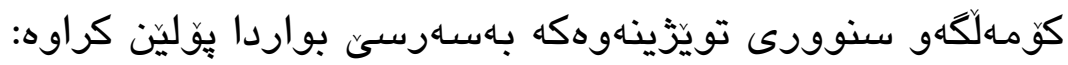

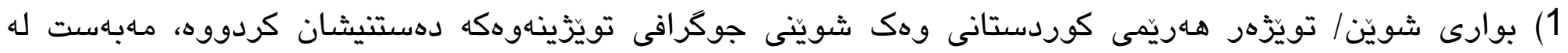

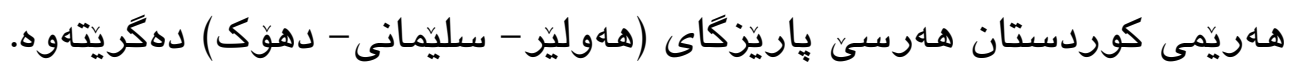

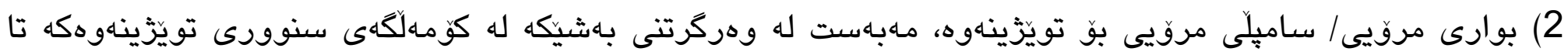

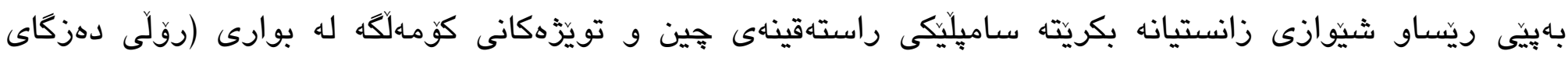

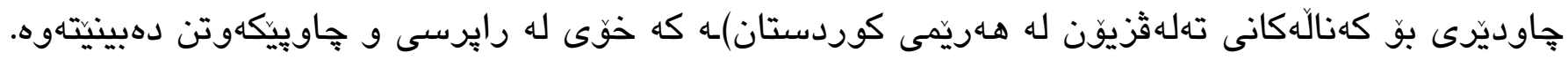

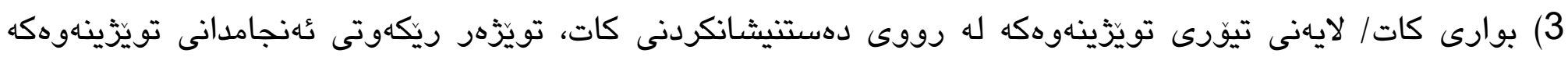

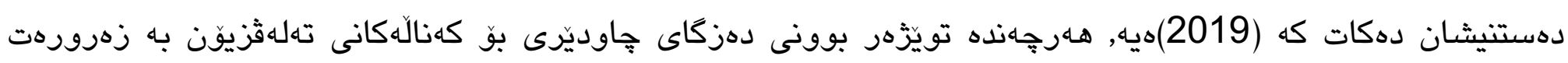

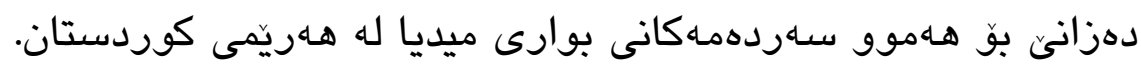

1- رينمايى و ياساو ريّسا بهركارهكانى راكهياندن له هـريّمى كوردستان، له تواناياندايه ئاسانكارى بوّ دامهزراندنى

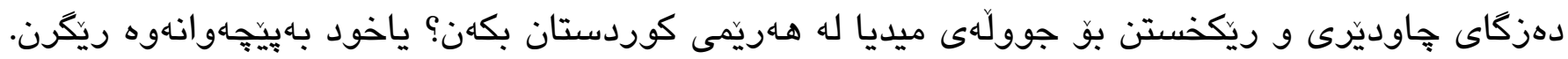

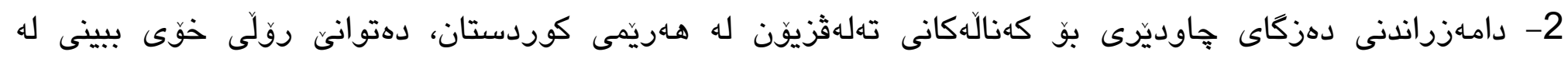

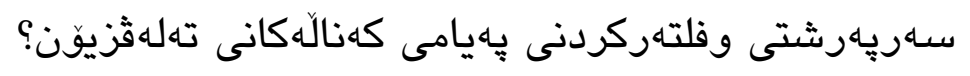

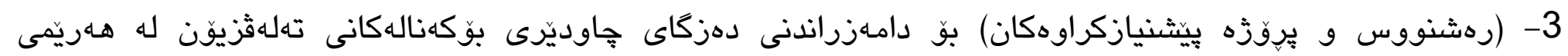

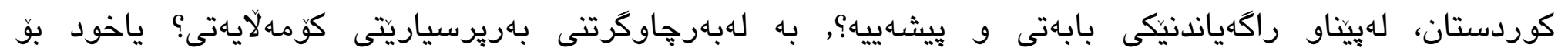

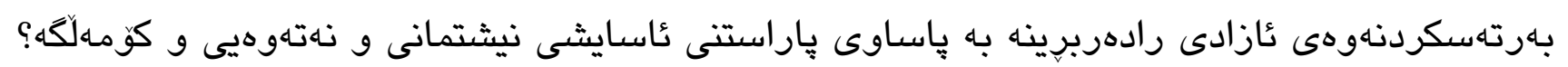

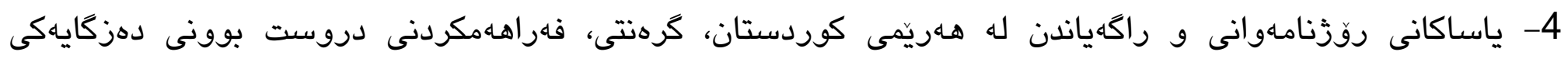

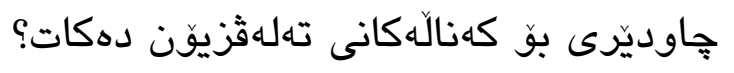

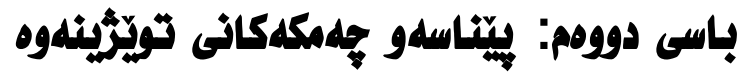 1-1-2}

ميديا له (معجم المصطلحات الأعلاميه) بهم جوّره بيّناساهى ميديا كراوه:

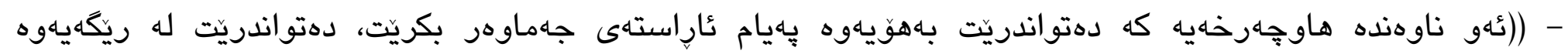

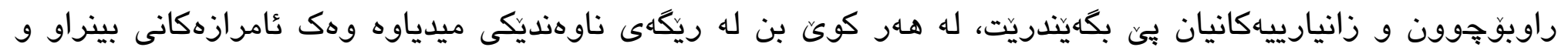


بيستراو و جايكراو كه ئهركى راكهياندن و ناراستهكرن و رِينمايى و هوَشياركردنهوهو رِوشنبيرى كردن و رِواجى

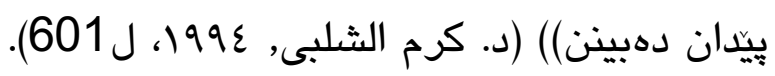

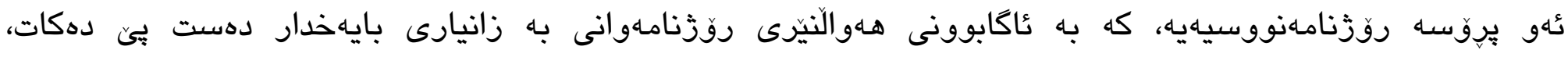

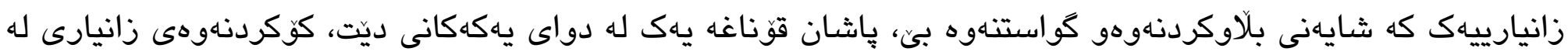

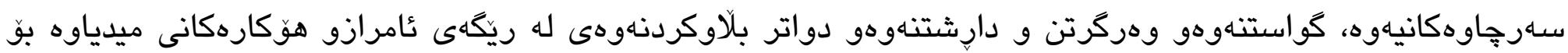

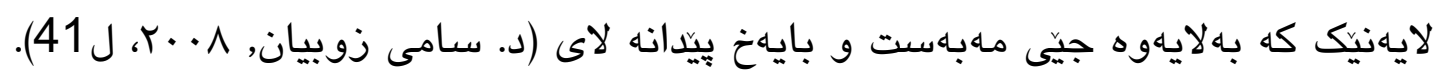

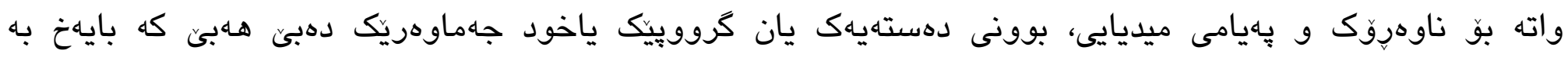

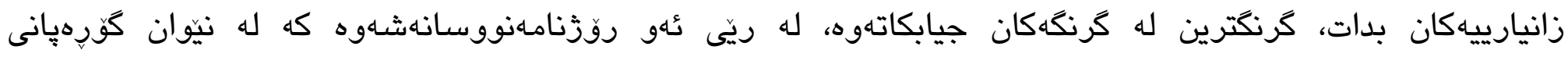

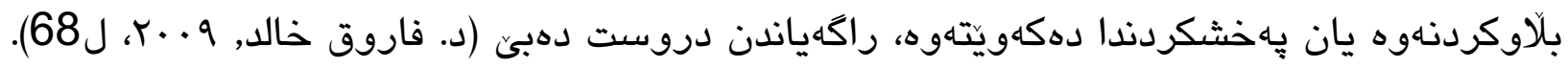

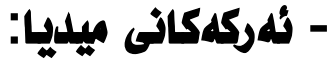

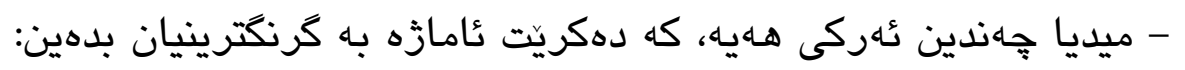

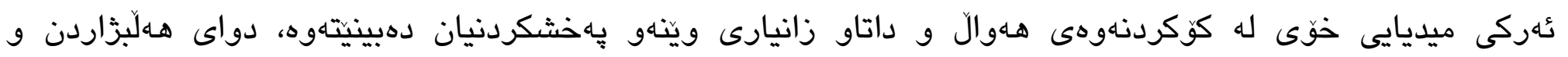

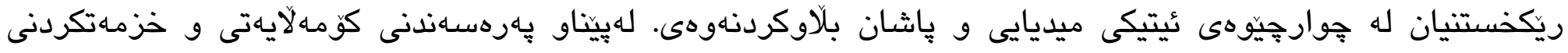
كومالخكاه, لهشيّوهى

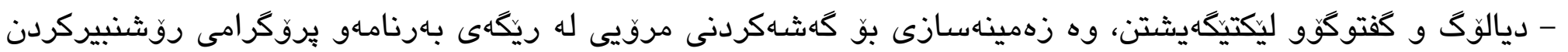

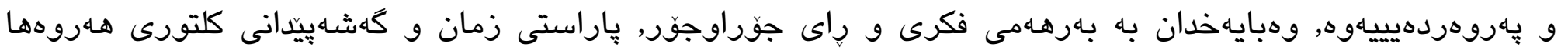

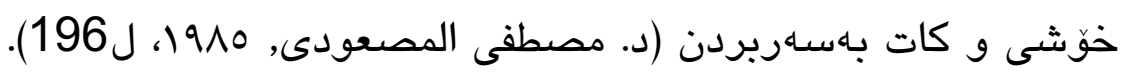

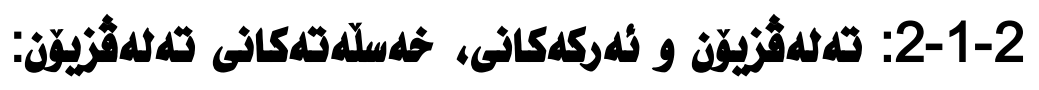

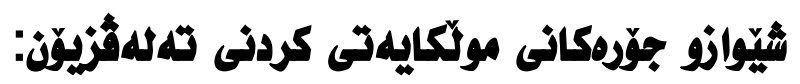

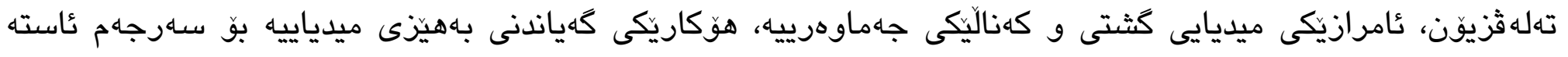

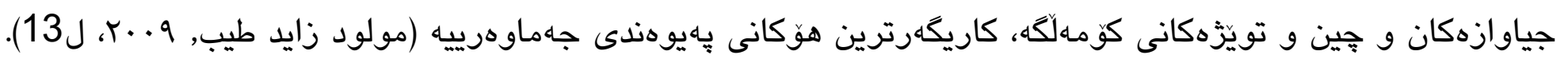

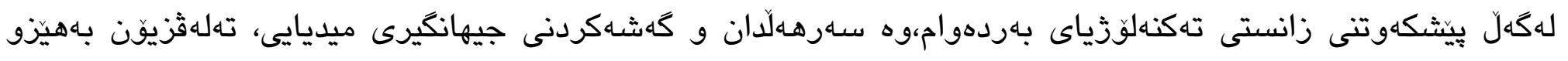

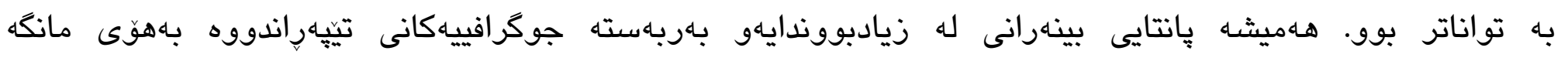

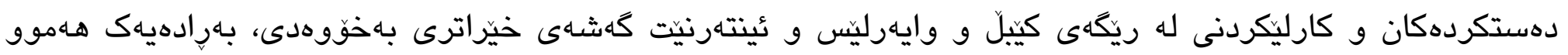




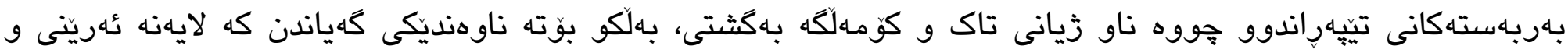
نهينيييهكانى زور فراوانترو كاريكاهرتر بوون (جون كورن,

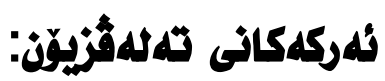

ميدياى بينراو وهك يهكيك له ناوهنده كرنكاكانى ميديا، جههندين ئهركى لهخو كرتووه، ئهو ئهركانهى تهله ثزيون رايان

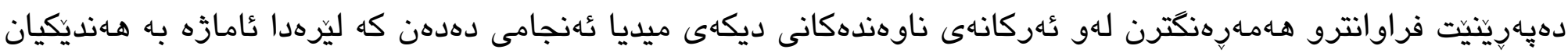

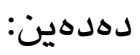

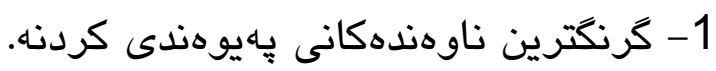

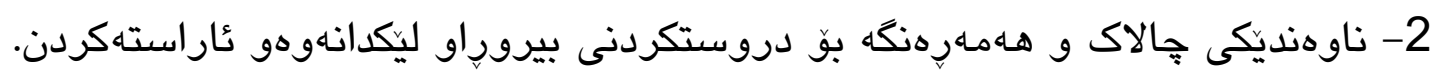
3- كئهركى روّشنبيرى يه.

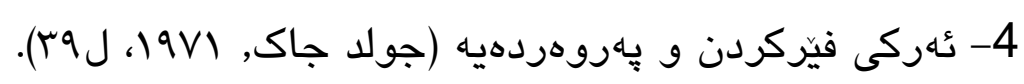

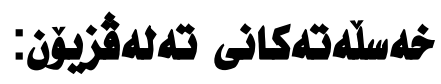

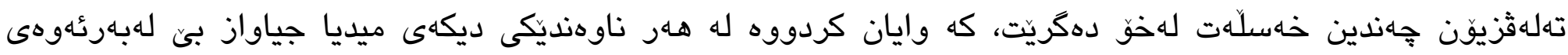

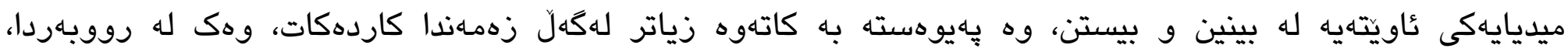

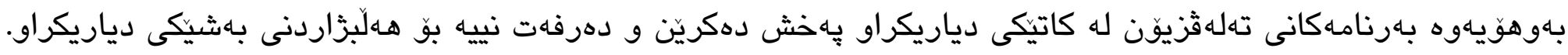

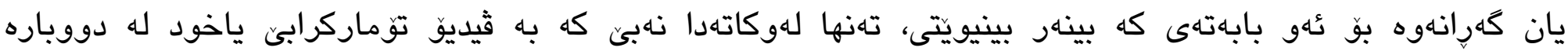

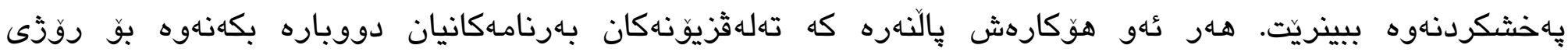

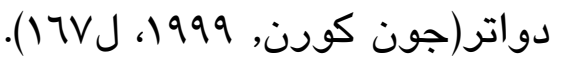

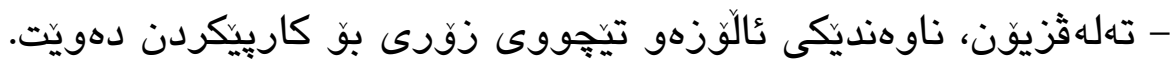

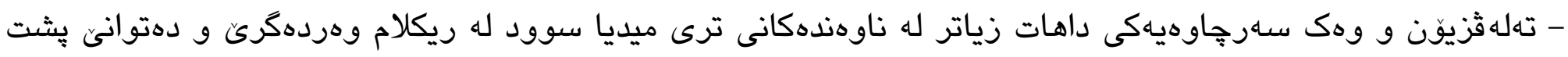
به داهاتهكهى بياهتئ.

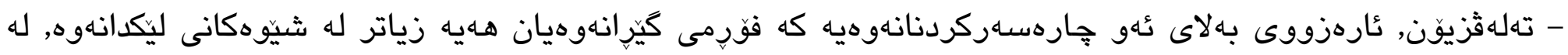

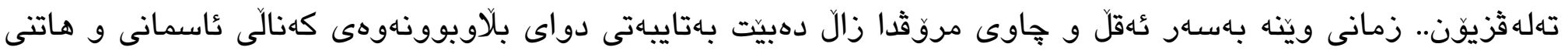

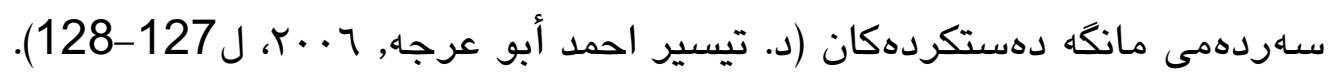

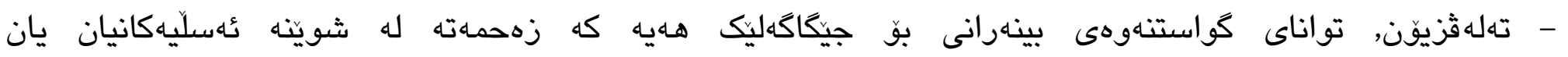

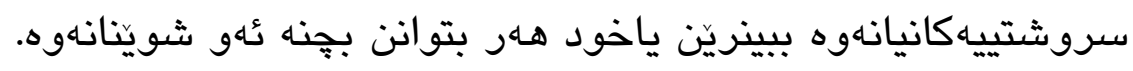




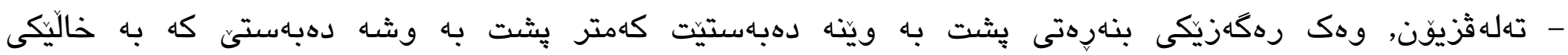

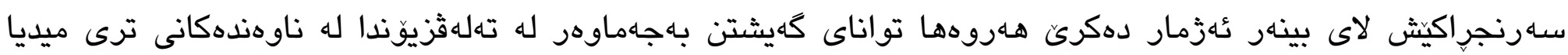

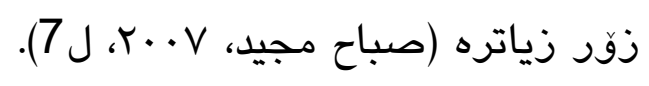

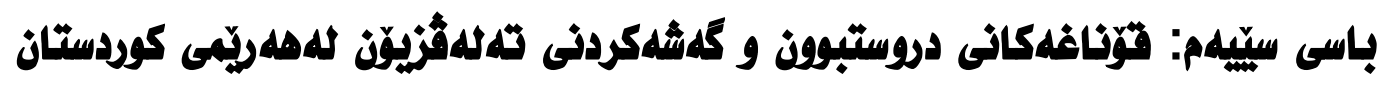

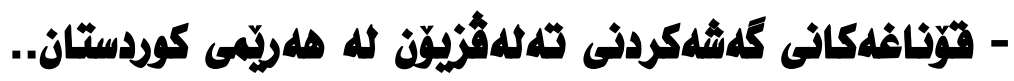

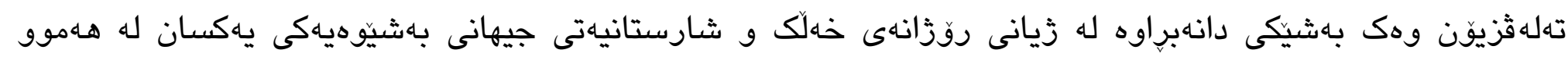

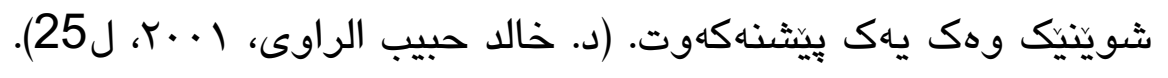

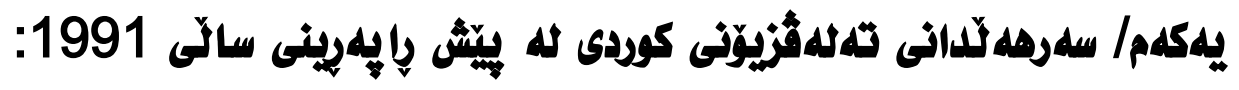

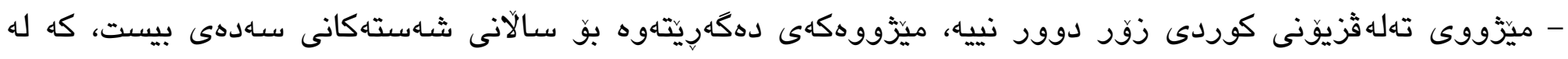

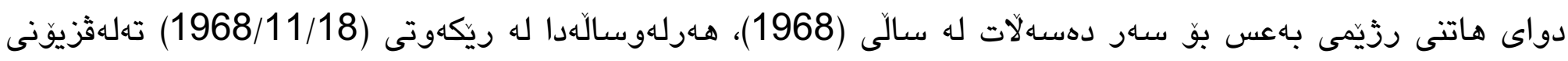

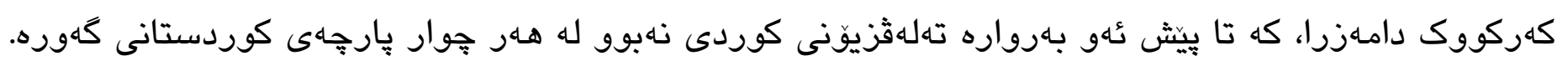

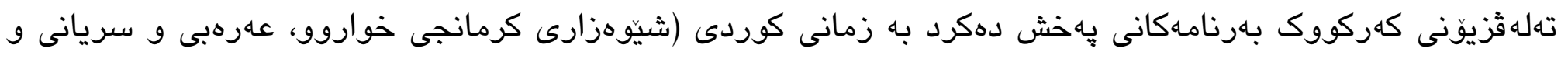

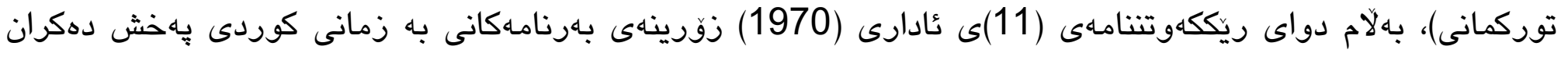

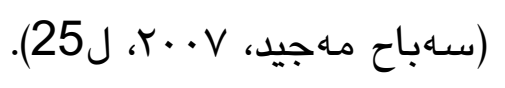

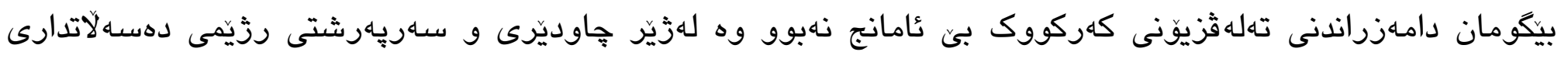

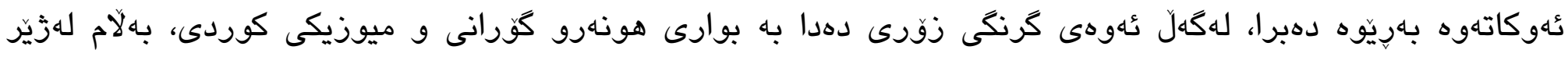

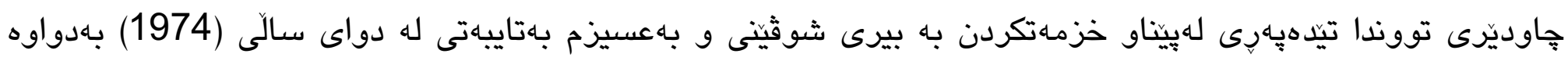

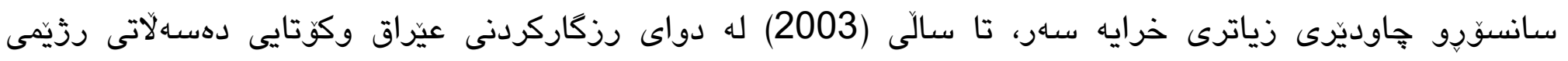

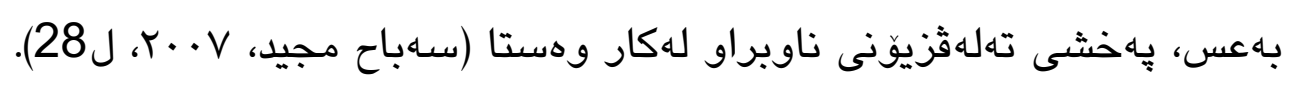

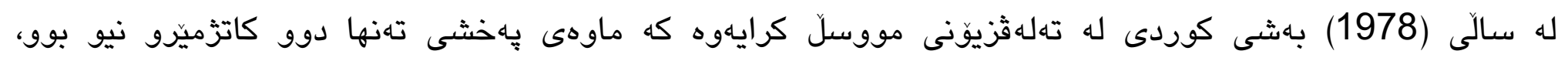

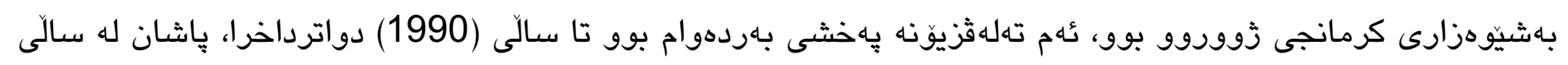

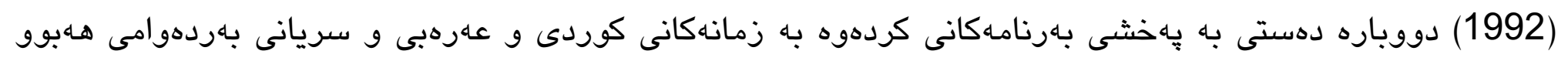
تا رووخانى رذيّمى بهاعس و عَازادكردنى عيّراق له (2003)دا. 


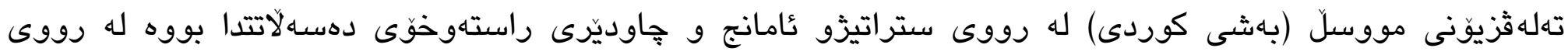

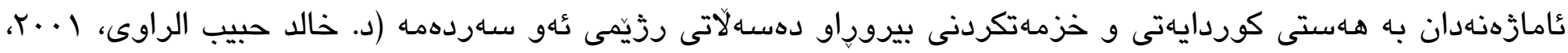

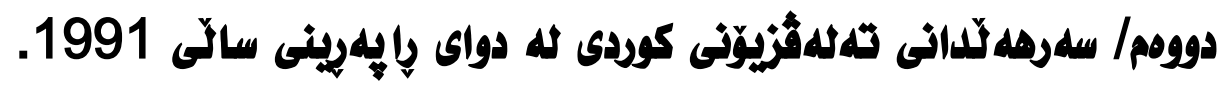

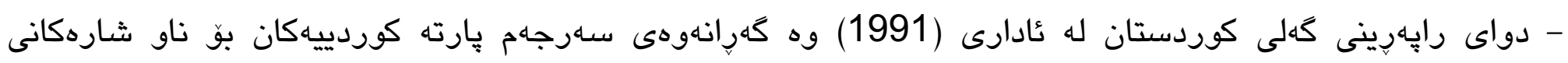

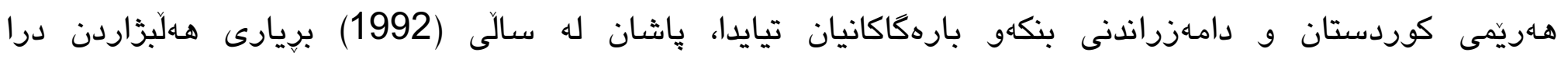

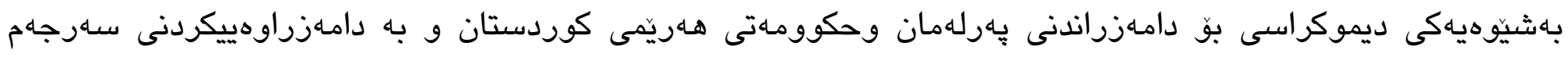
كايهكانى حوكمرانى.

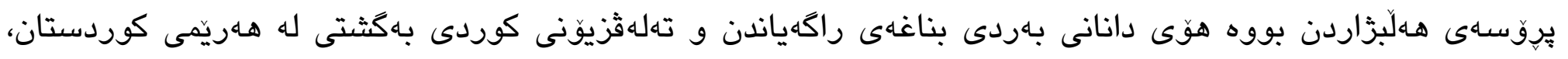

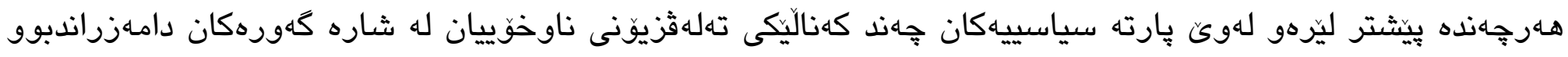

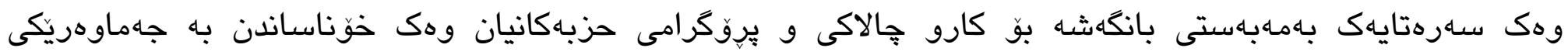

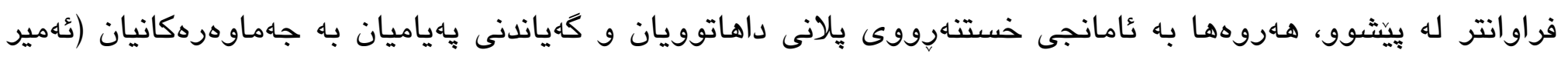

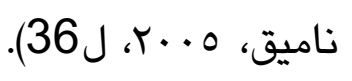

يهكهم تهلهزيونى ناوخق له دواى رايهرين له (1991/9/11) دامهزرا له شارى سله سليمانى لهلايهن يهكيتى نيشتمانى

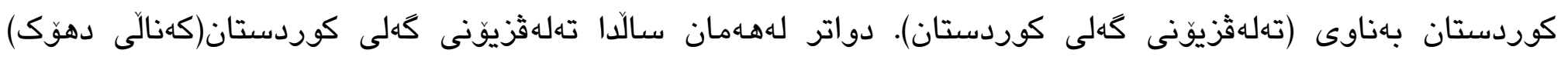

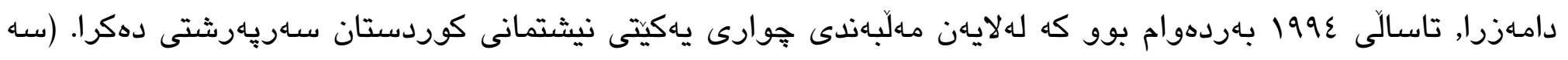

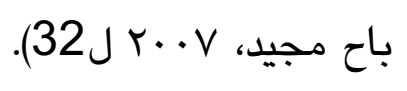

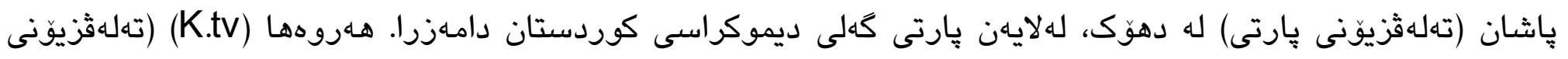

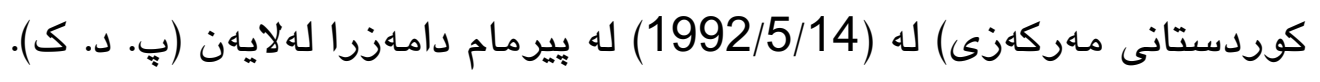

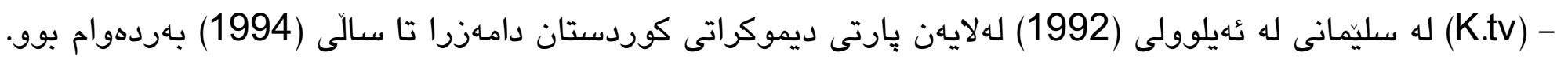

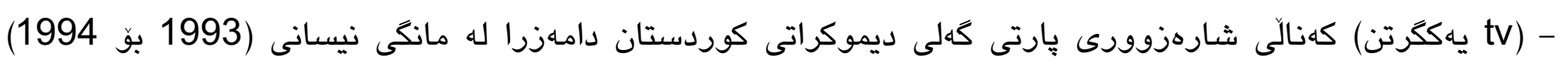
بهردهوامى هـبوو.

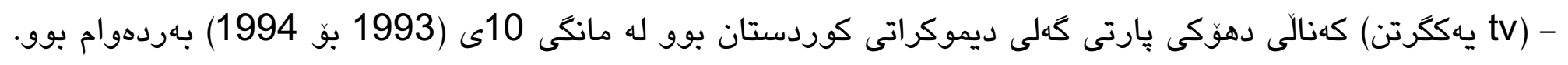

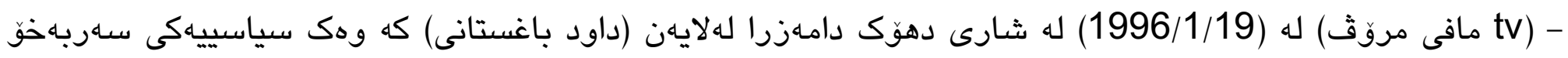

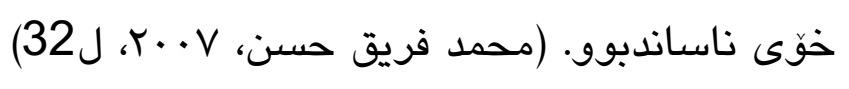

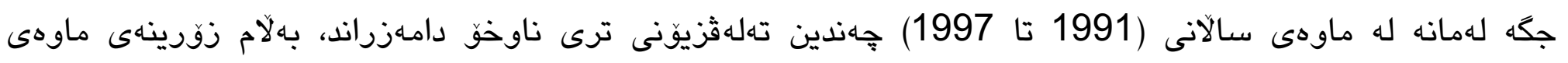

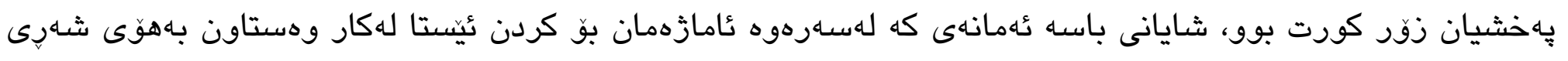




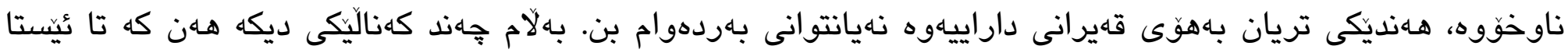

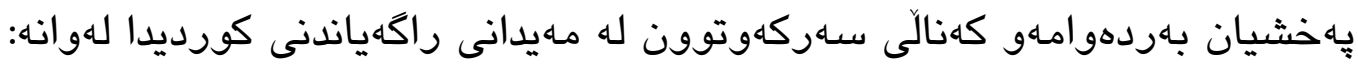

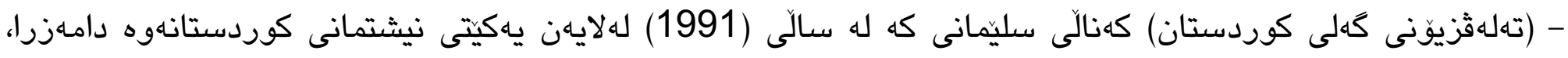

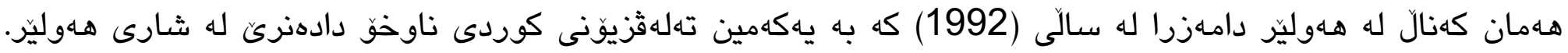

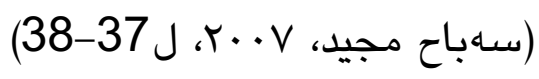

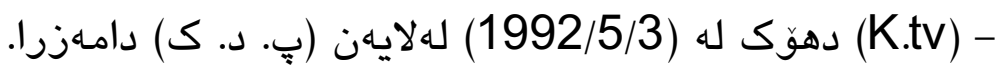
(K.tv) -

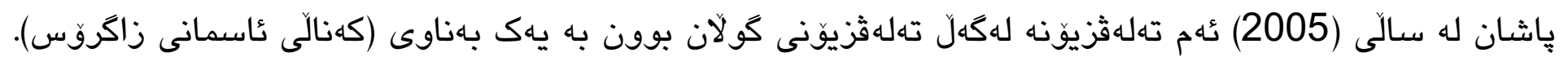

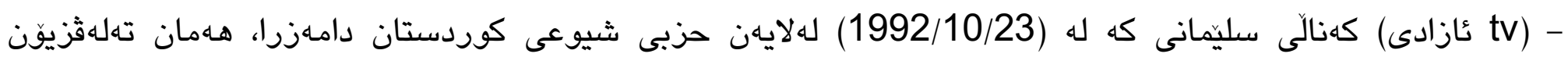

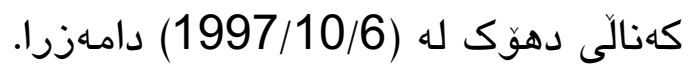

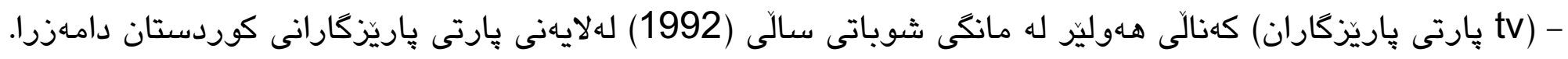

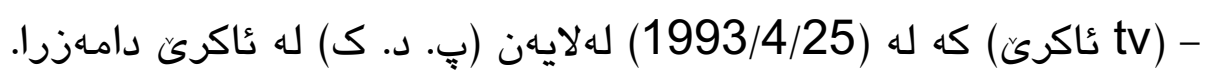

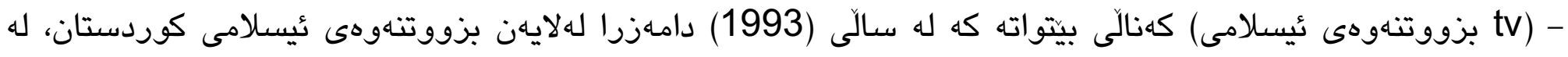

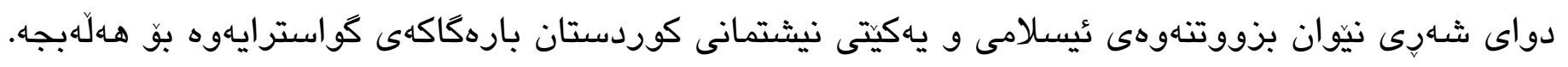

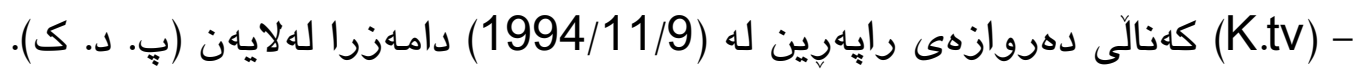

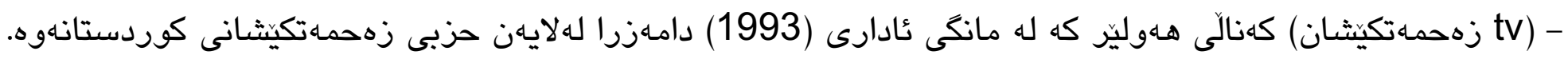

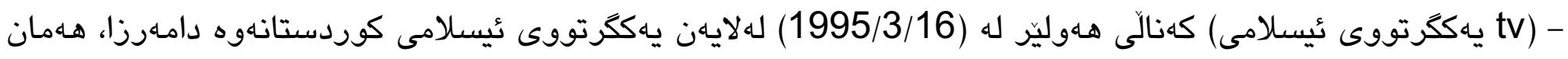

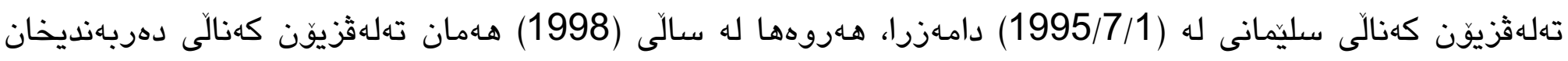
دامـزرا.

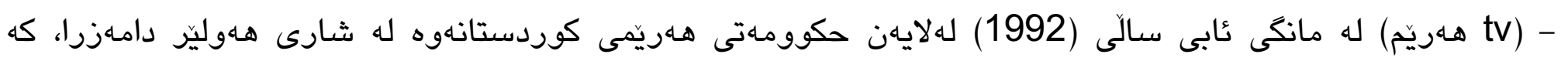

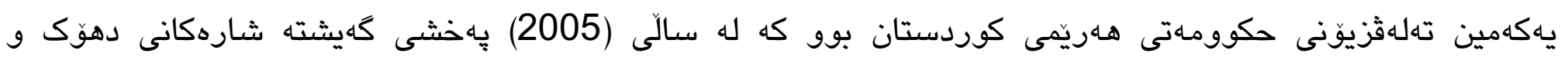

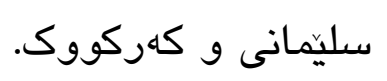

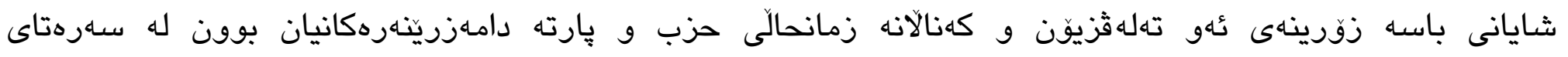

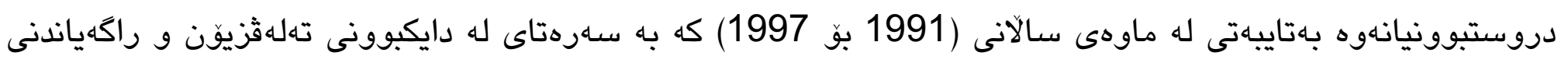

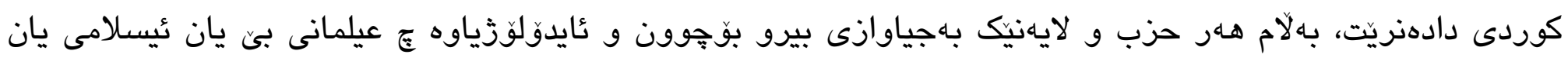

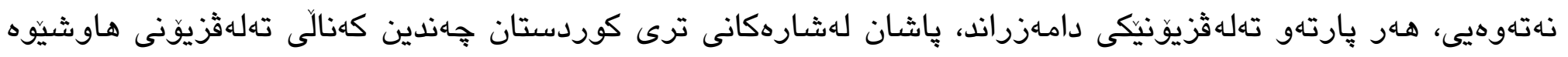




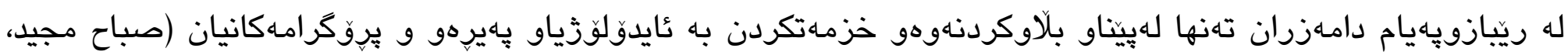
.(41-39...V

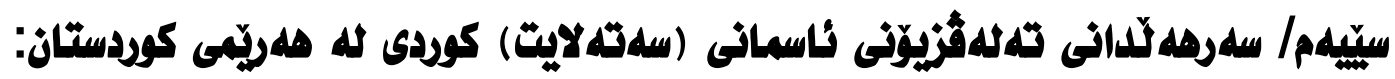

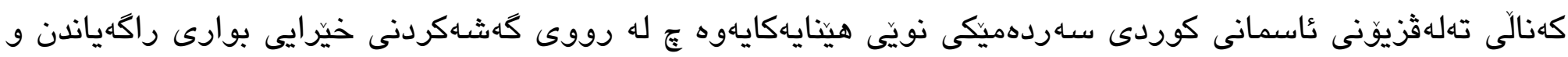

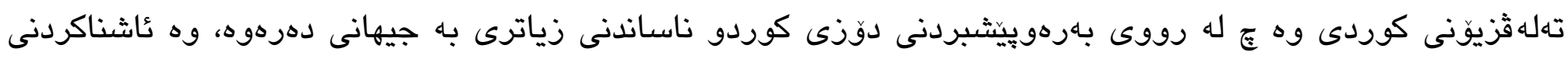

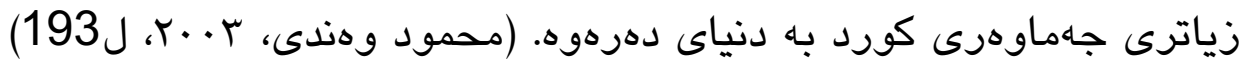

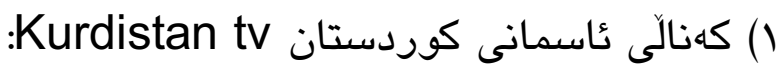

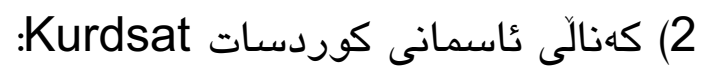

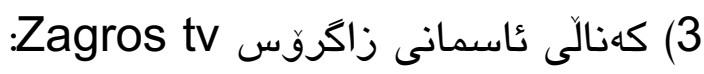

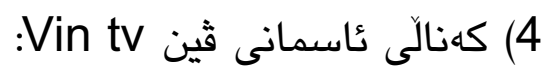

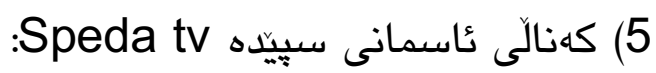

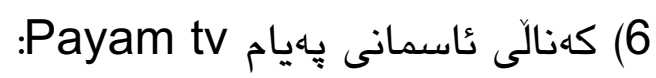

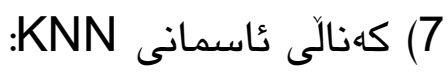
9) كهنالّ عاسمانى كُلى كوردستان Gali Kurdistan:

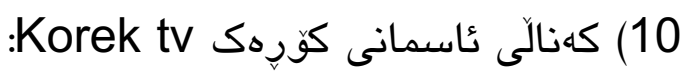

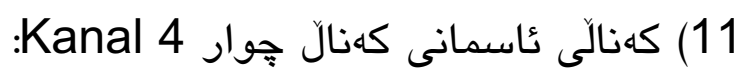

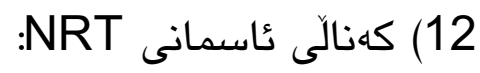

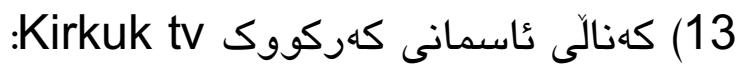

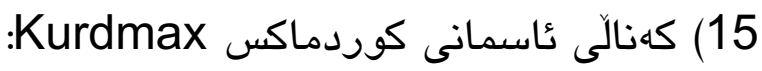

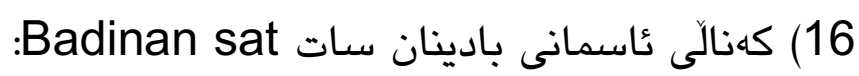

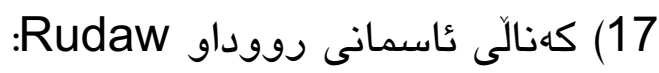
18) كهنالَى ناسمانى ريكًا Rega

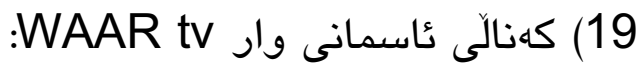

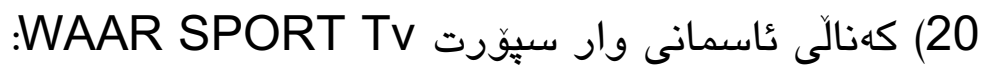
K24 كهنالَى عاسمانى : 21 


\section{باسى جهوارهم: جهاوديّرى للهوووى زماثلهوانييلهوه}

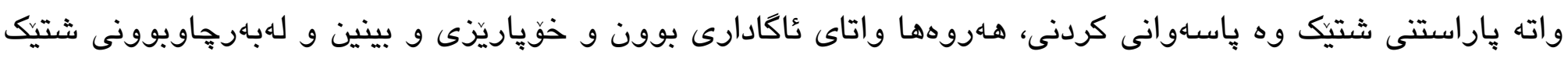

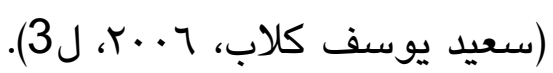
وشـهى جاوديّرى له فهرههنكى (مختار الصحاح) هاتووه: به واتاى پِاريّزكارى و جاوديّرى (محمد بن ابى بكر الرازى، (252) (251) (191)

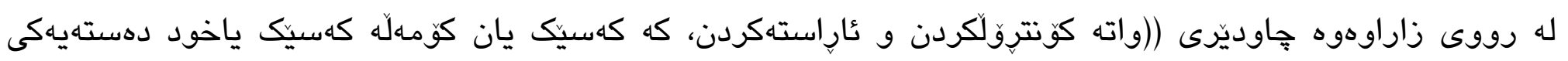

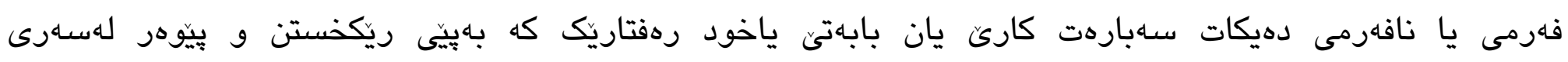

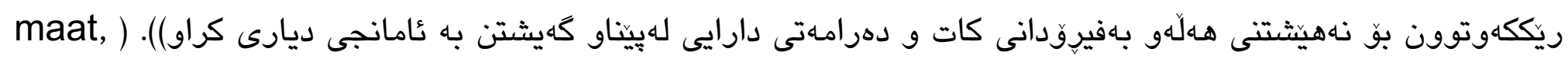
online $(2010$

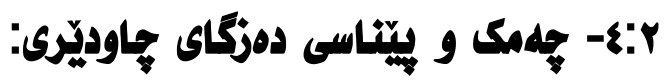

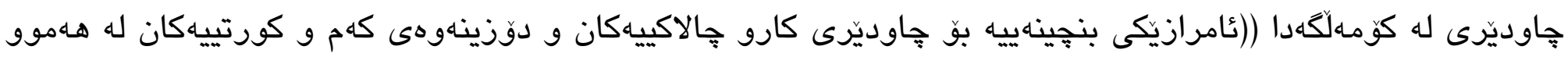

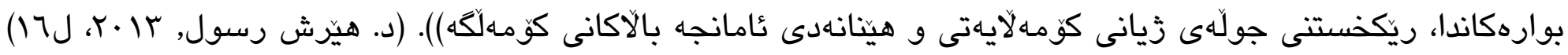

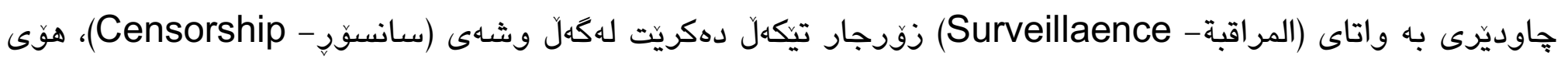

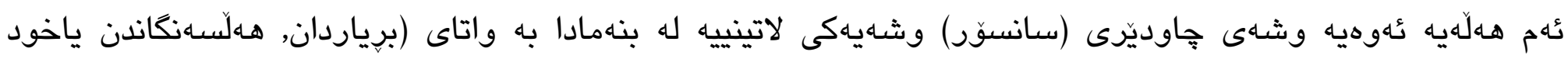

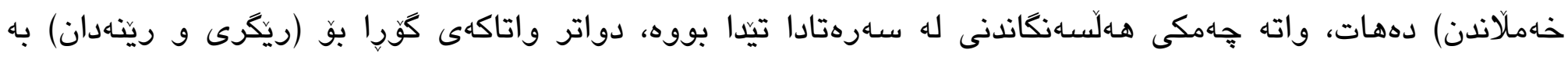

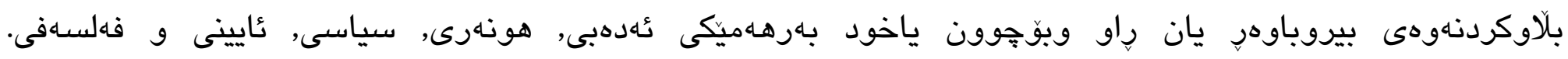

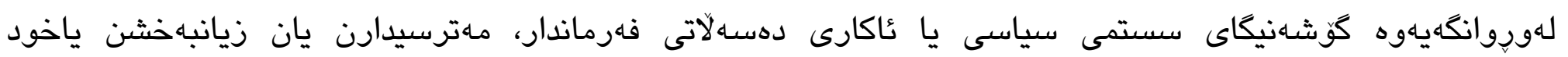

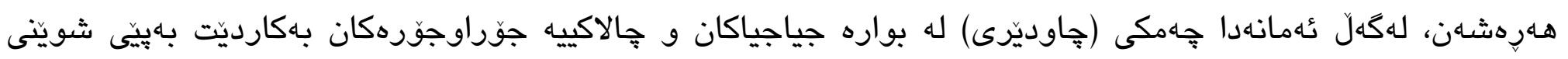
وشهاكه له بوارهكهدا دهكوريّيت.

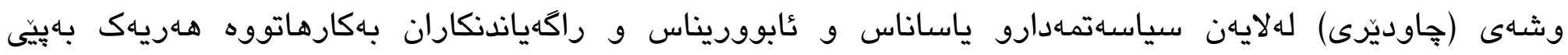

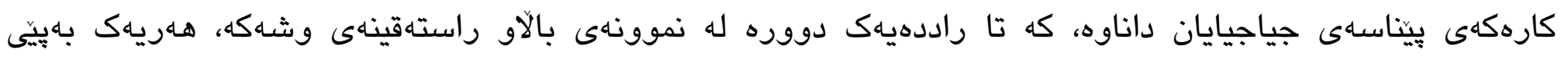

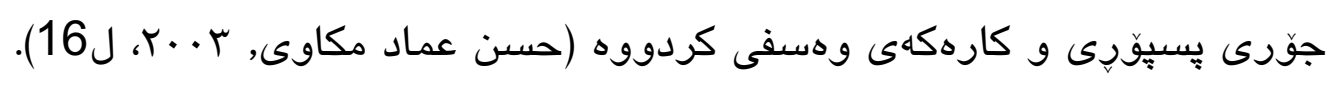




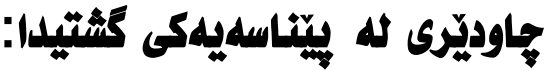

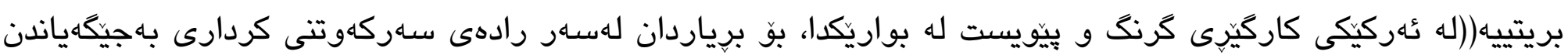

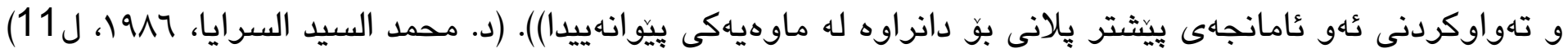
ههروهها ئيراهيم الداقوقى جاوديّرى بهوه وهسف دهكات كه ((شاردنهوهو وهلانانى ئهو بيرو بوّجوونانهى ناكوكن لهكهل

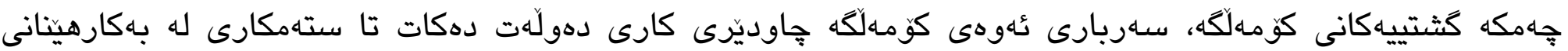

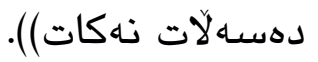

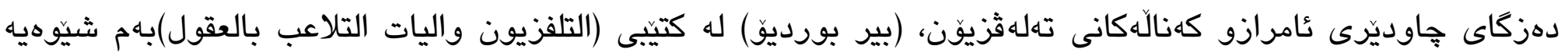

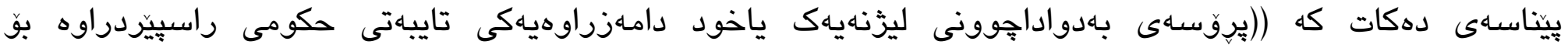

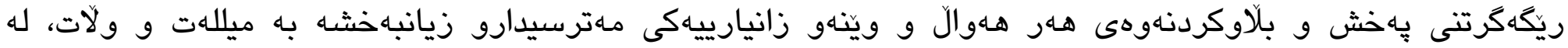

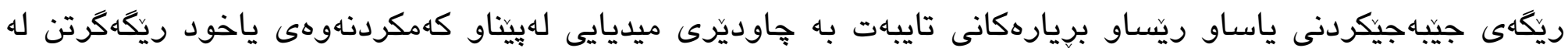

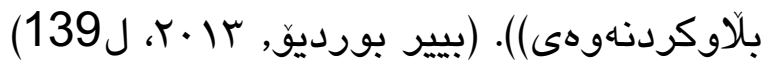

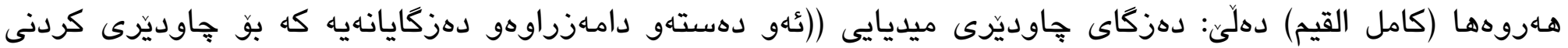

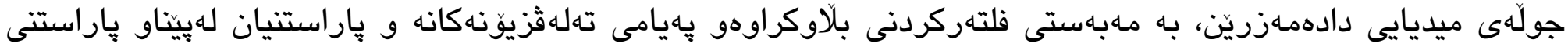

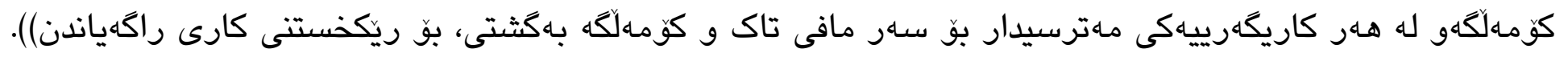

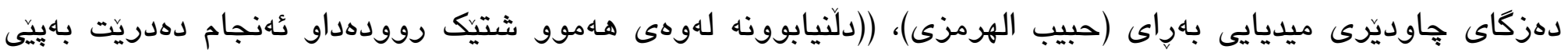

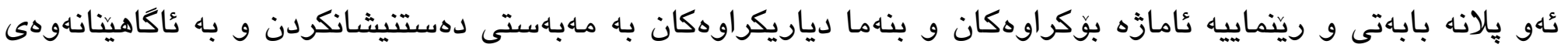

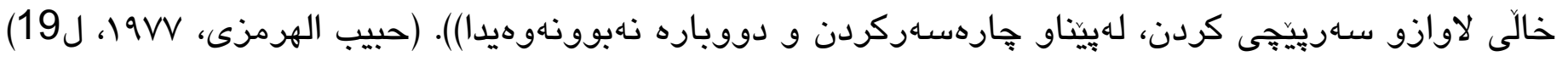

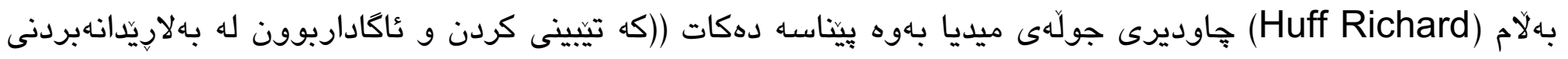

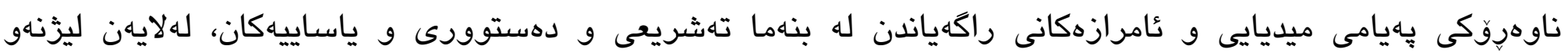

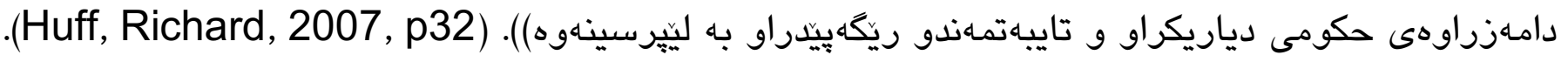

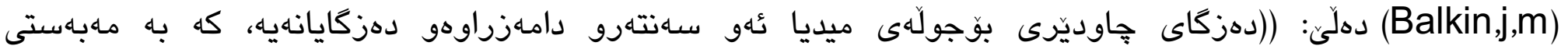

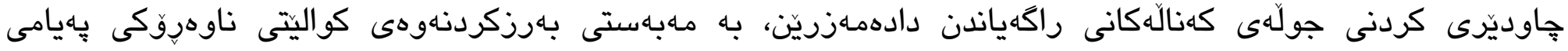

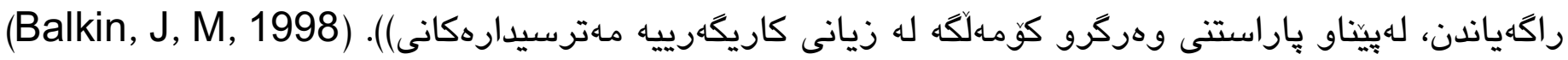

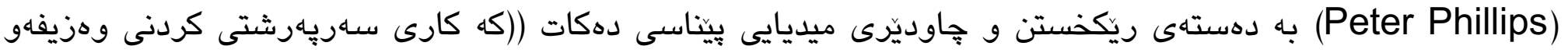
كارو جالاكى ثٔامرازهانى بينراو و بيستراو و جاب و بلاّوكردنهوهيه، بو دلّيابوون له يهكانكيرى لهكَلّ بنهماو ياساو ريّاكان و ئيتيكى دوزّنامهوانى، كه لهلايهن دهستهو دامهزراوهى فهرمى ياخود ريكخراوهيى نافهرمى ئهنجام دهدريت)).

(Peter Phillips, 2007, p18) 


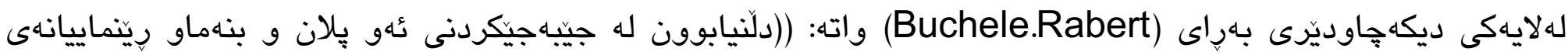

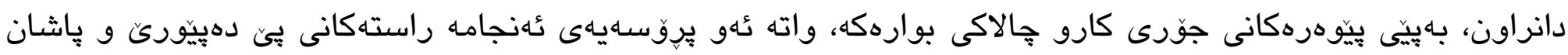

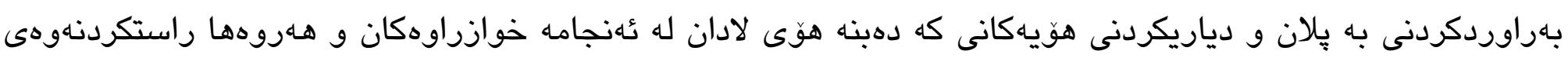

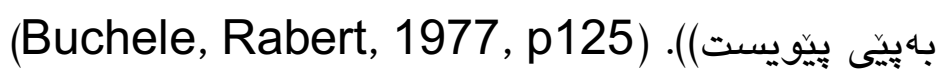

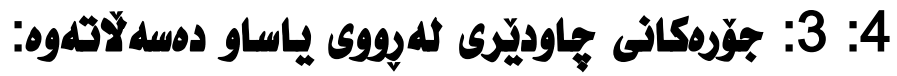

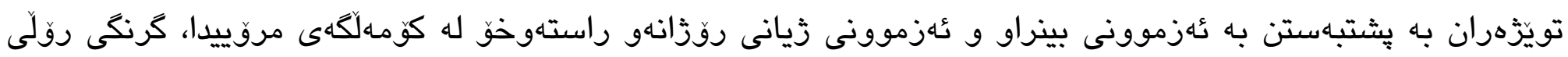

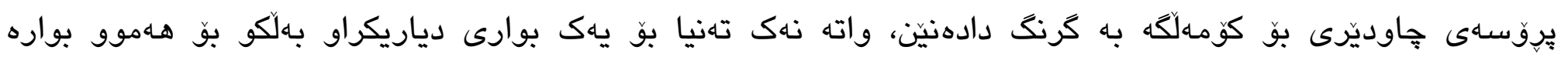
جياجياكانى زيان له كومهالكَّدا.

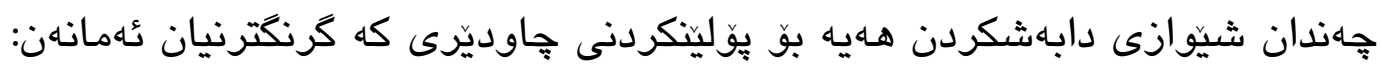

$$
\text { 2- 1- جهاوديّرى كاركيّرى. }
$$

3- جاوديَّىى ياسايى دادوهرى.

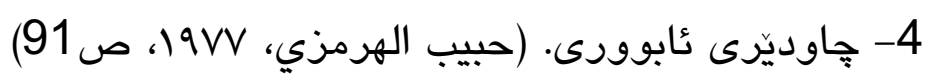

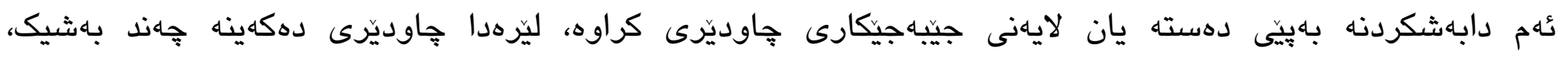

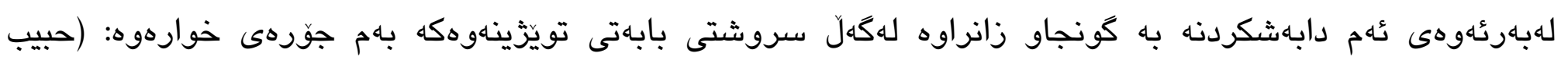

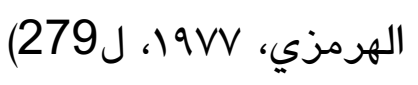

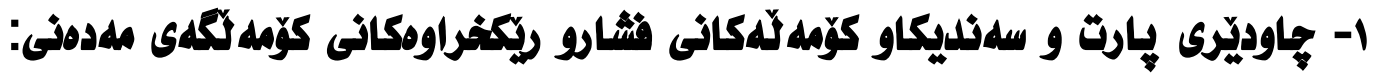

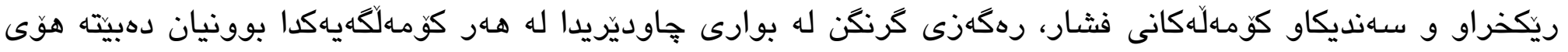

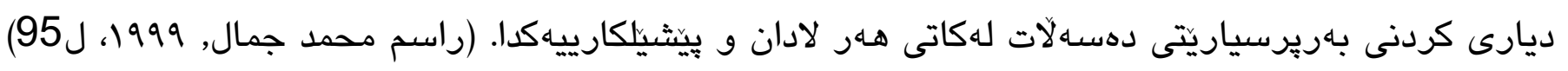

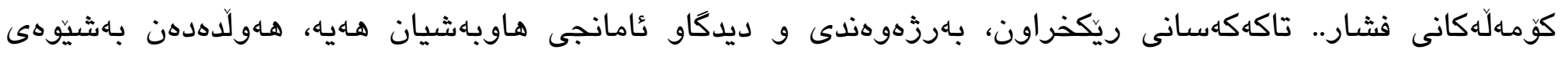

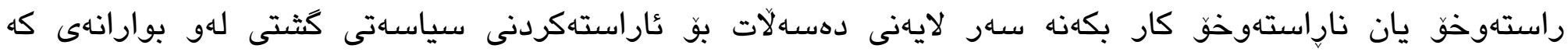

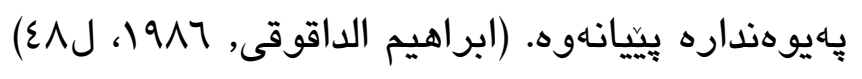

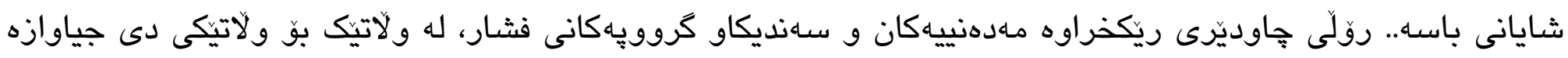

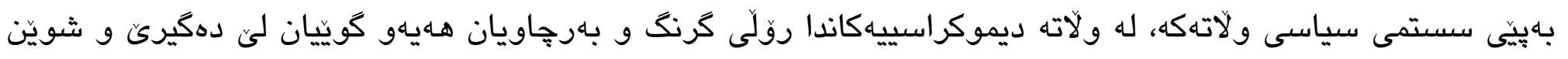

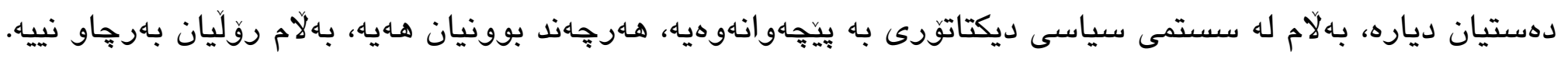

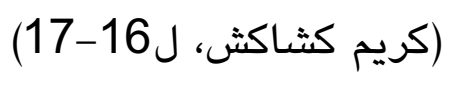




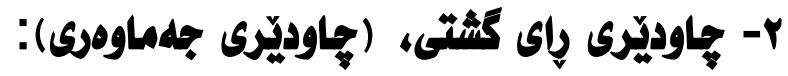

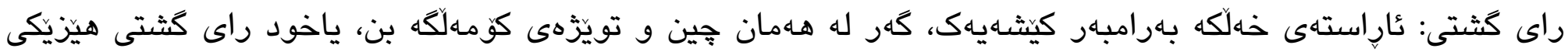

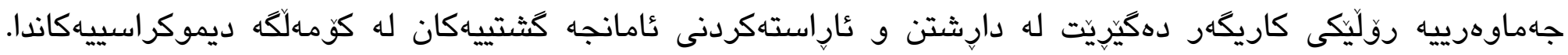

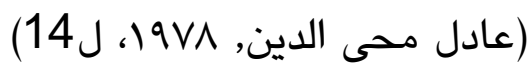

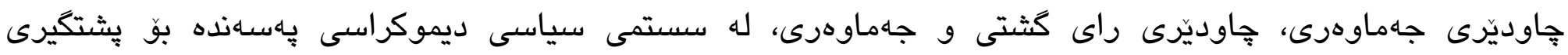

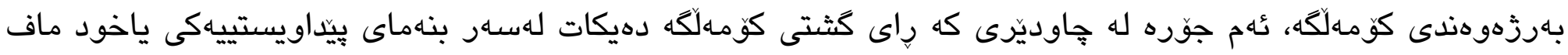

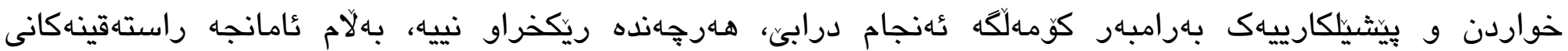

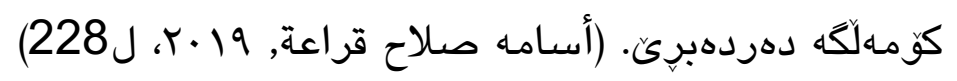

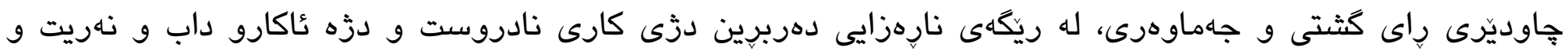

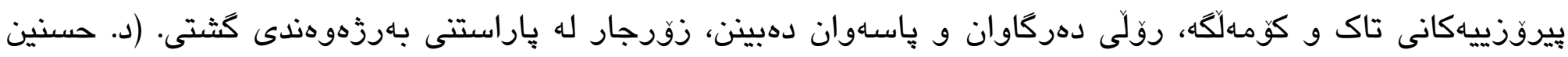
عبدالقادر, 197r، ل6161)

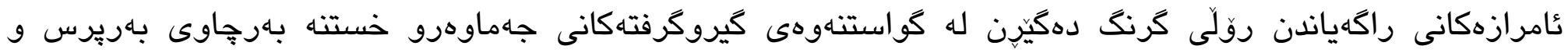

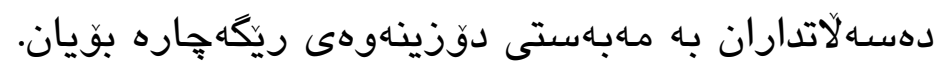

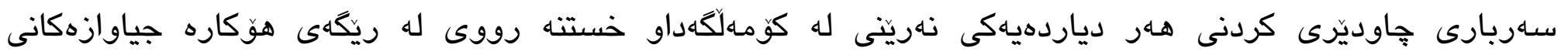

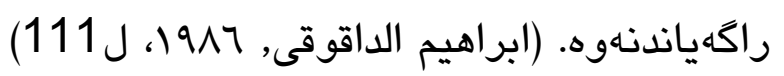

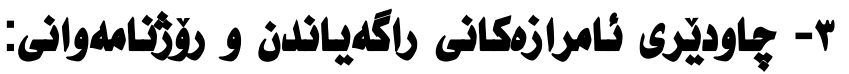

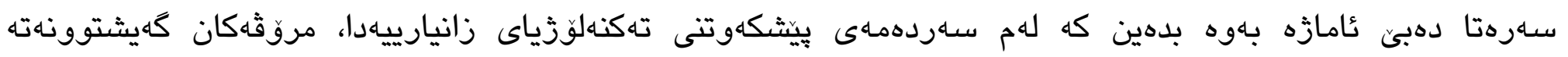

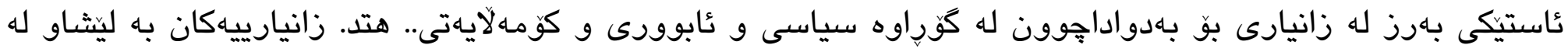

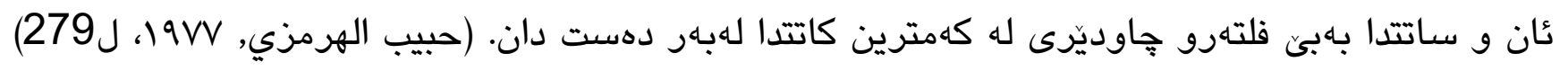

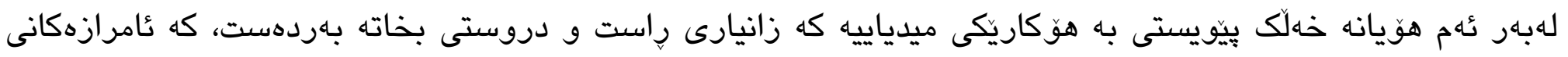

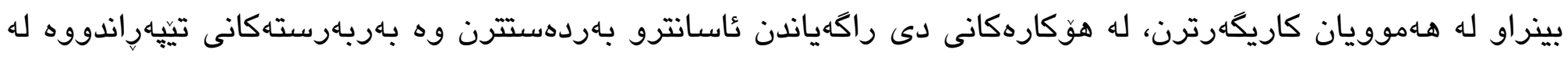

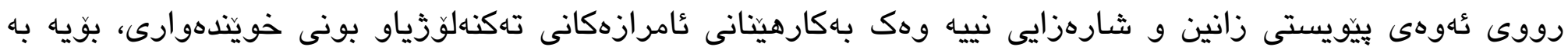

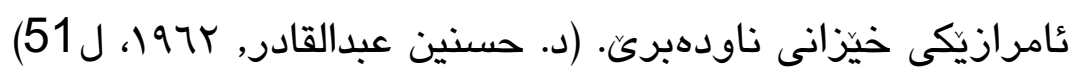

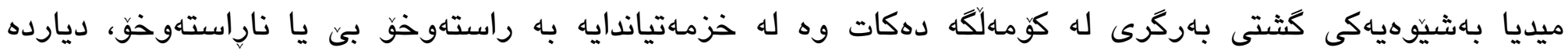

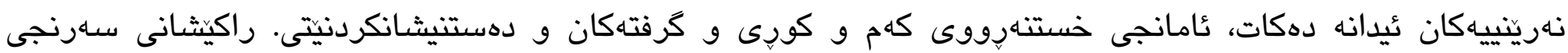

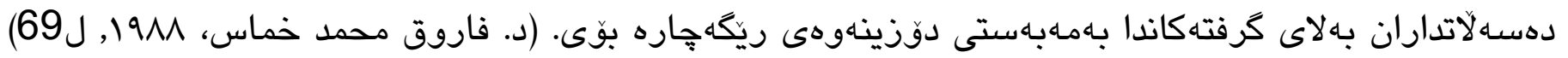




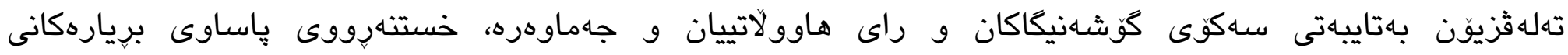

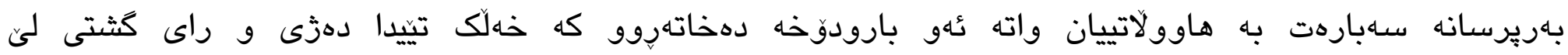

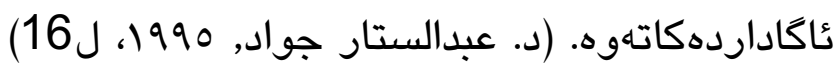

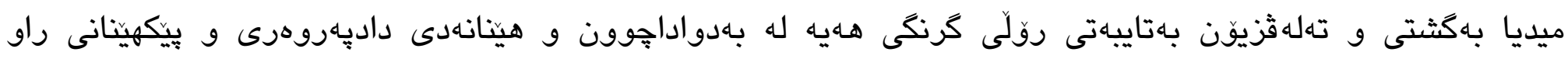

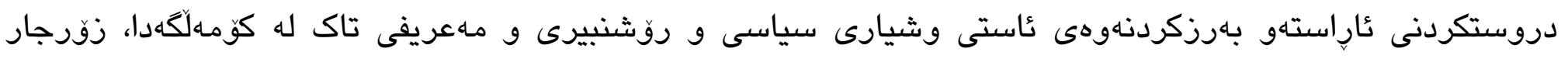

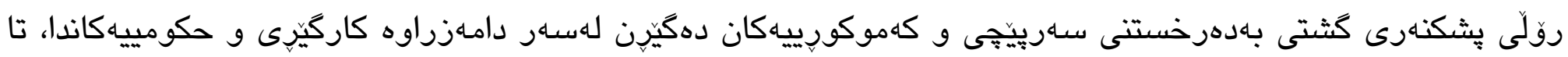

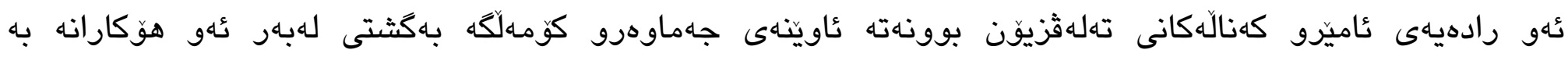

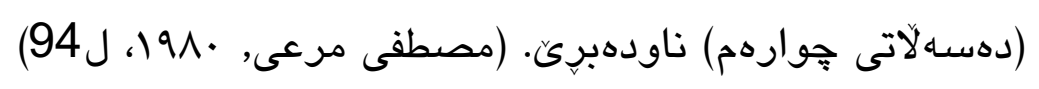

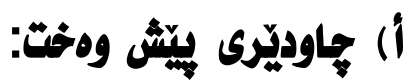

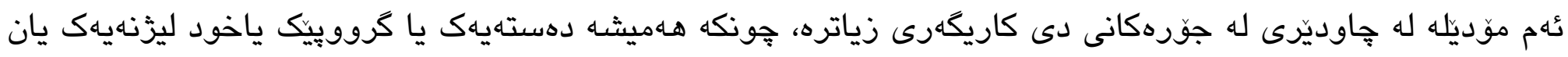

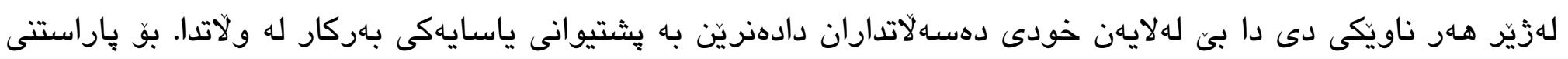

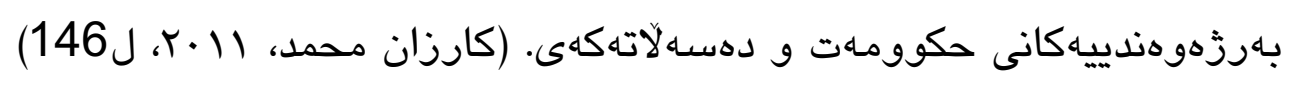

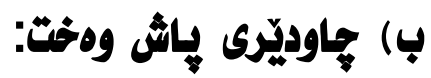

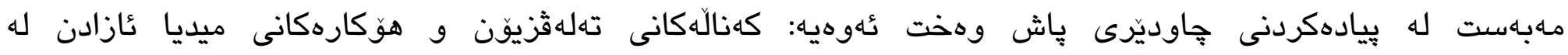

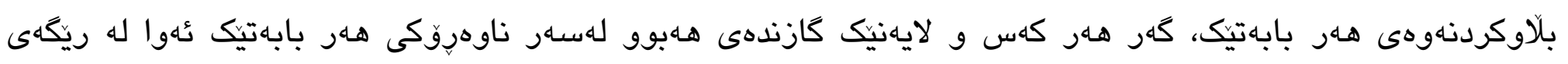

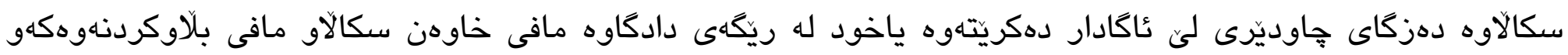

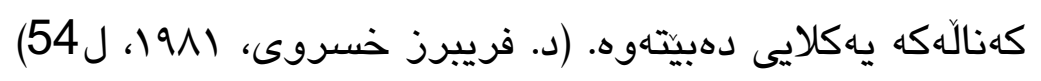

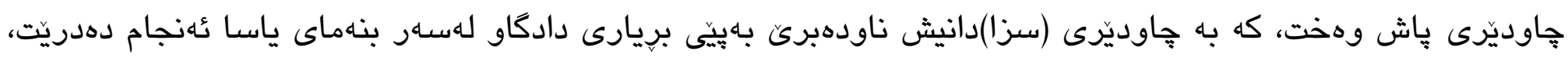

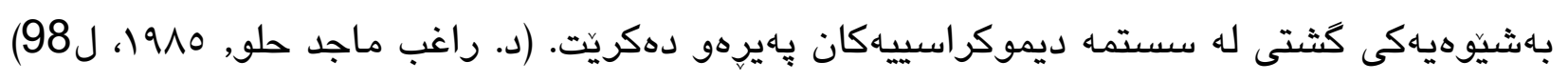

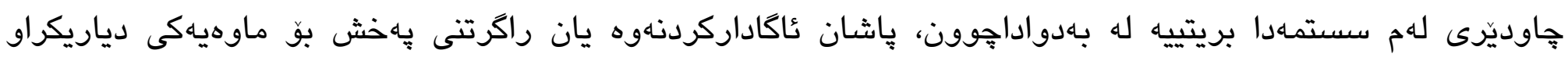

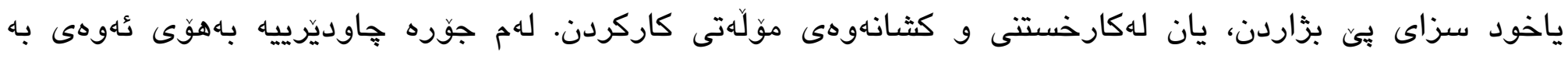

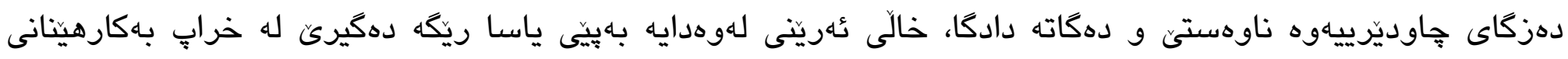

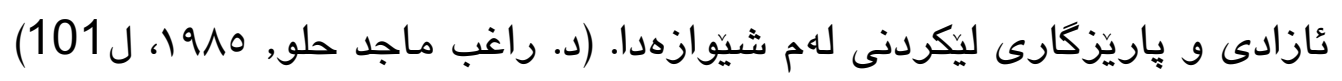

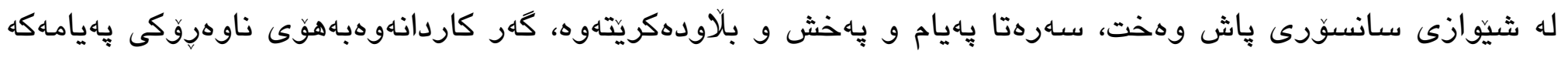

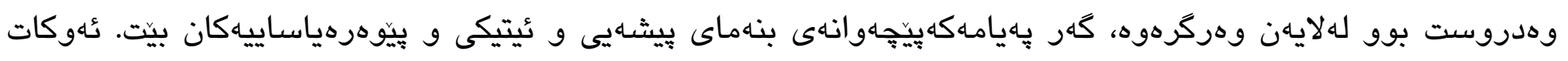

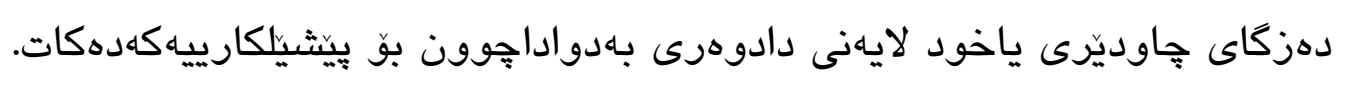




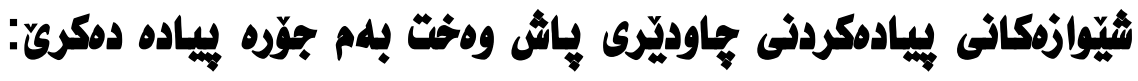

ا- ريّنمايى و جاوديّرى خودى:

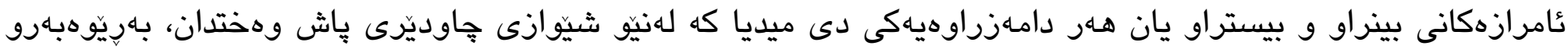

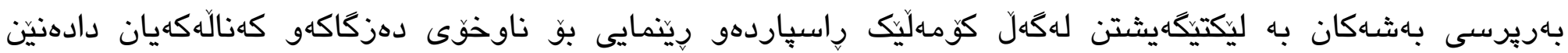

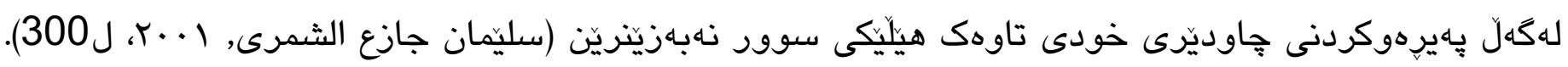

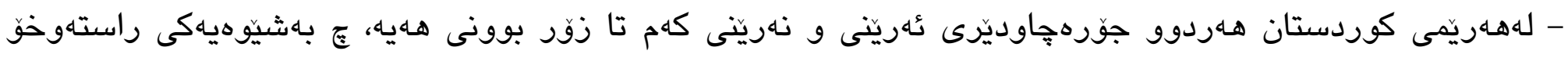

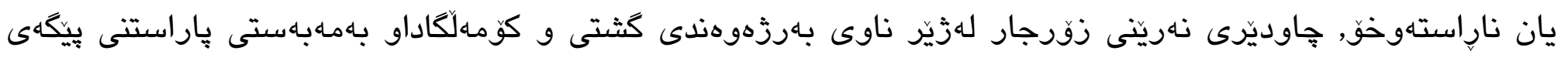

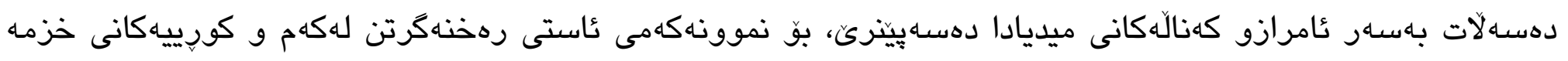

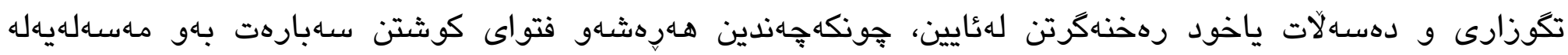
كوردستان هلبووه.

\section{ب- دانانى دمركاوان:}

دهركاوان به كرنكترين و باشترين فلتهر دادهنركّ بهراى شارهزايانى بوارى ميديا، جهامكى دهركاوان بو يهكهمين جار

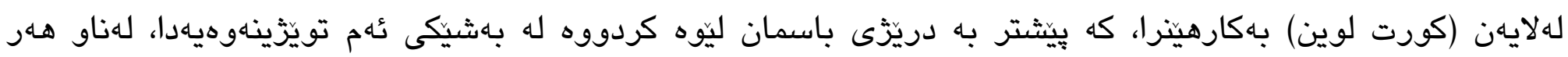

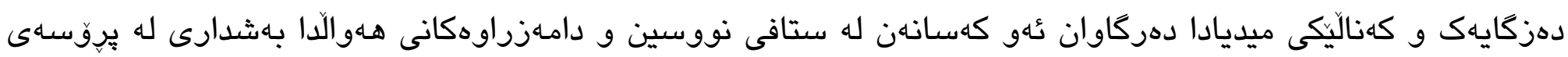

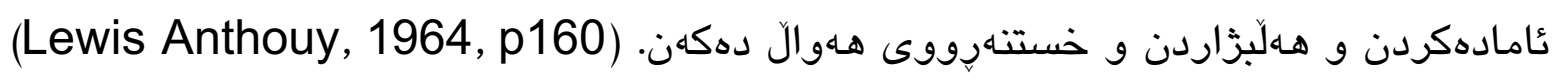

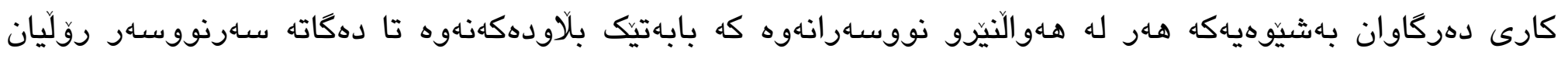

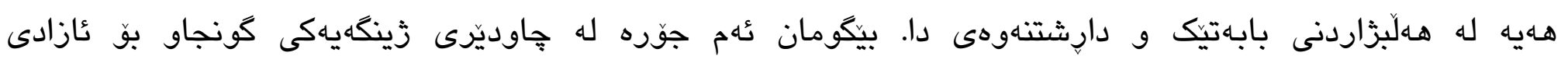

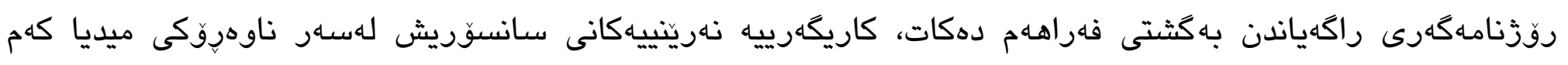

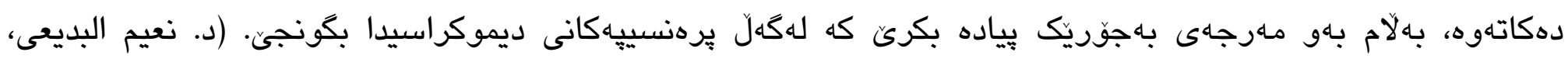
(r) J, r.. 9

\section{ج- فتلهره تهكثيكييلكان:}

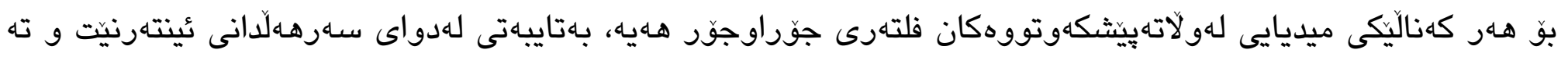

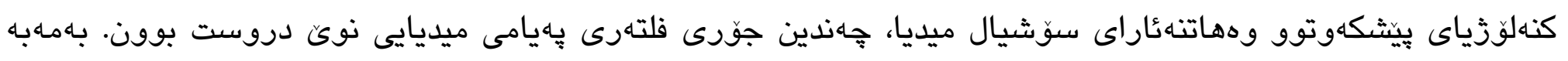

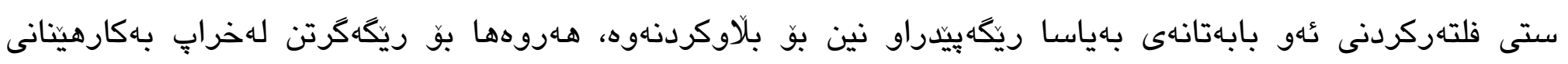

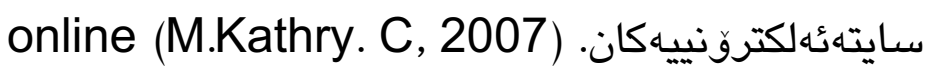




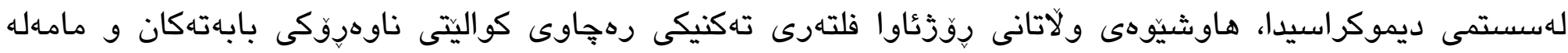

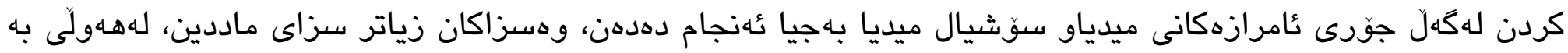

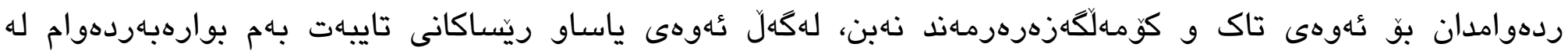

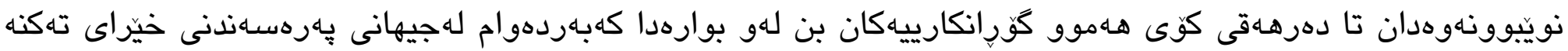

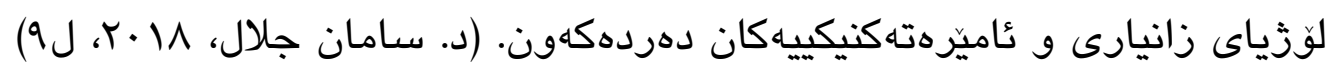

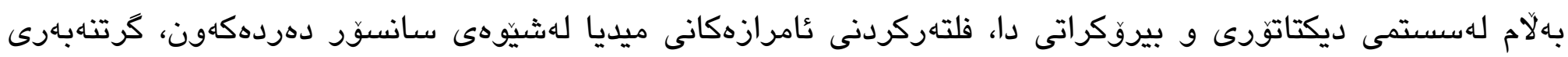

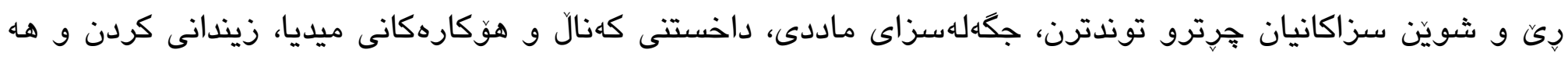

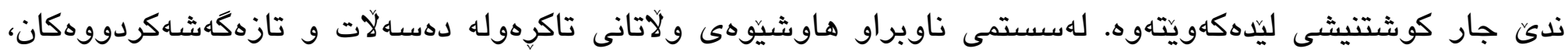

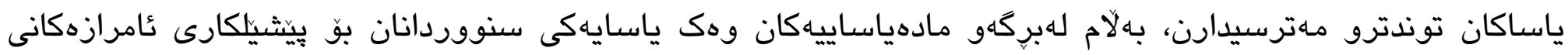

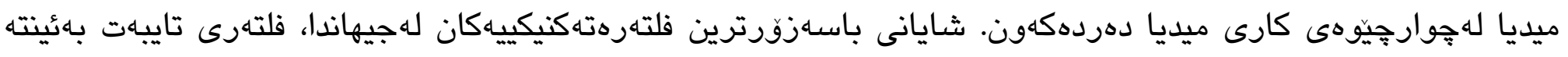

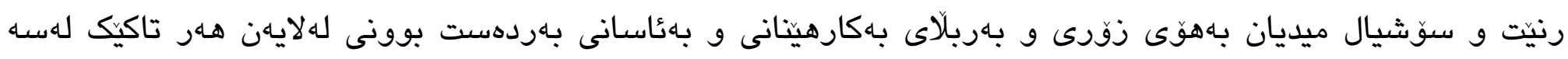

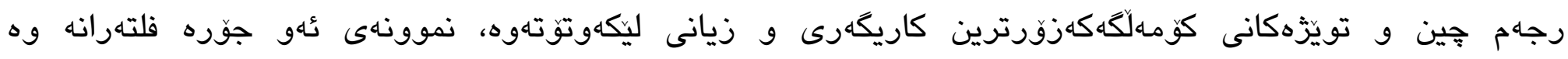

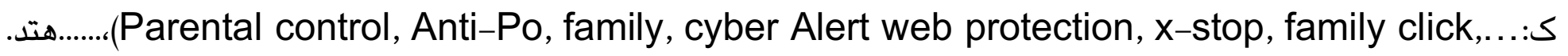

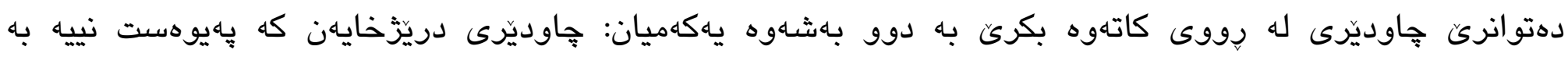

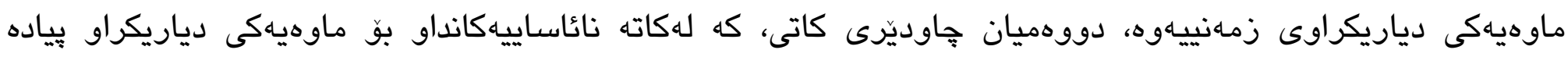
دهكري وهك له خوارهوه باسيان دهكهين:

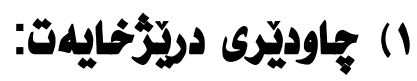

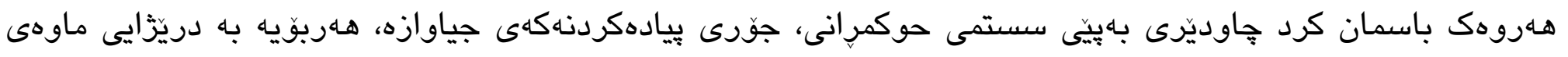

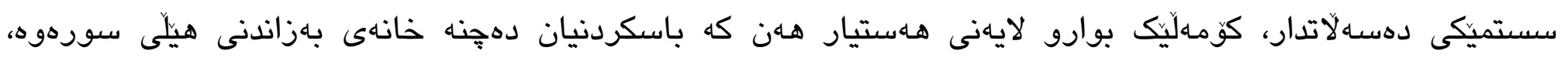

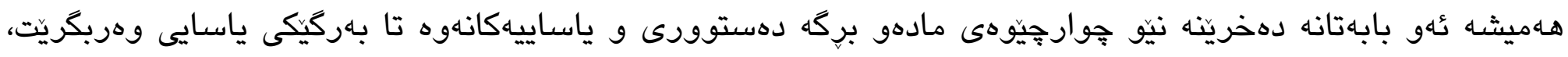

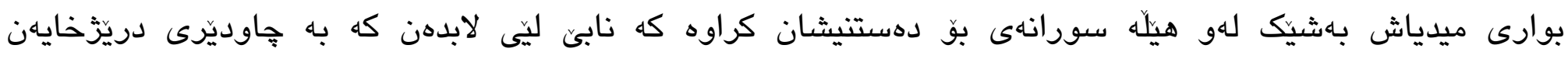

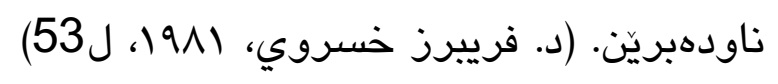

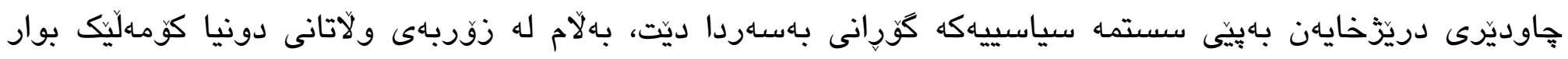

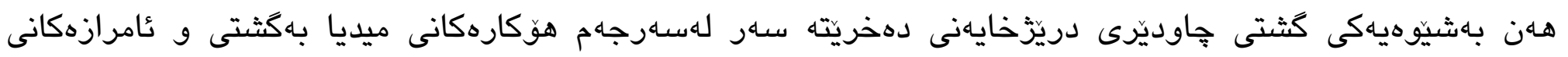
بينراو بهتايبهتى، وهك: 


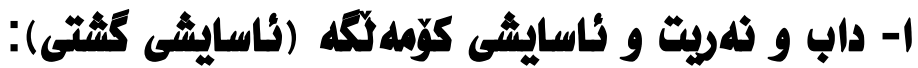

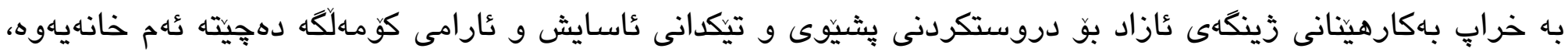

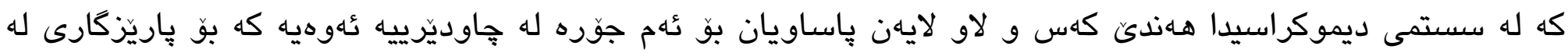

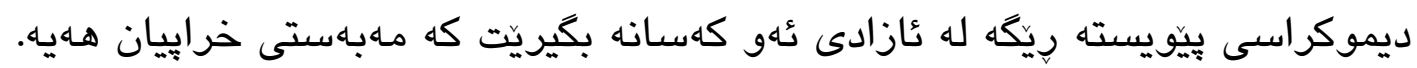

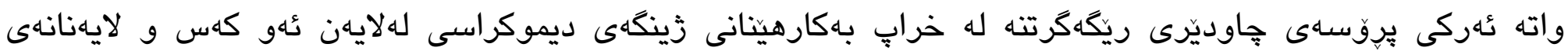

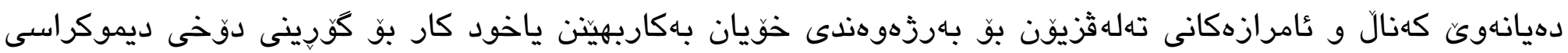

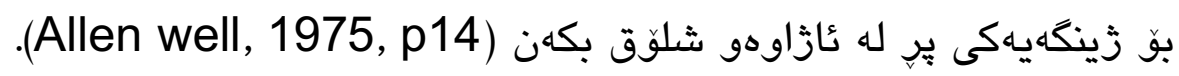

\section{ب- بيروباوهور نائين و ناينزا:}

له هـريّى كوردستان ئايينى جوّراوجوّر بوونى هاهيه، وهك (ئيسلام، مهسيح،جوو، ئهرمهن, يهزيدى) ههروهها ئاينزاو

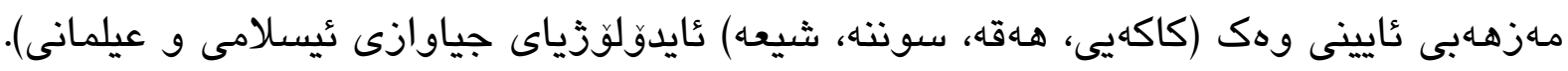

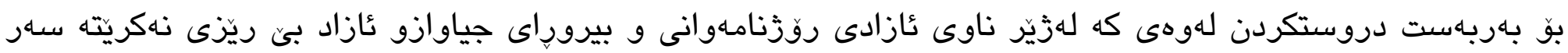

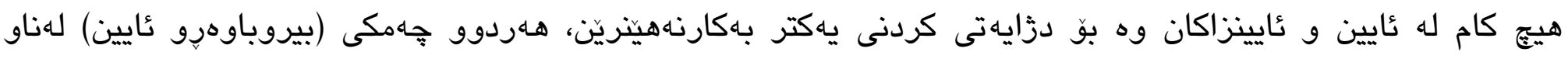

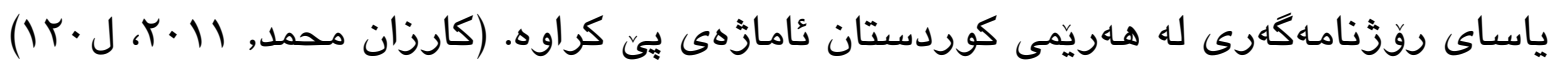

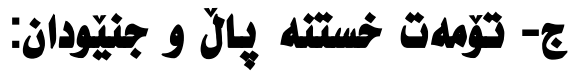

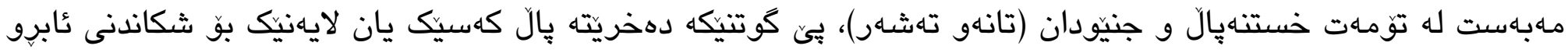

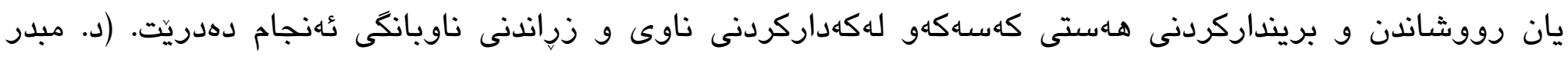

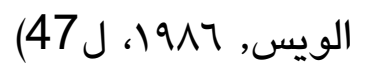

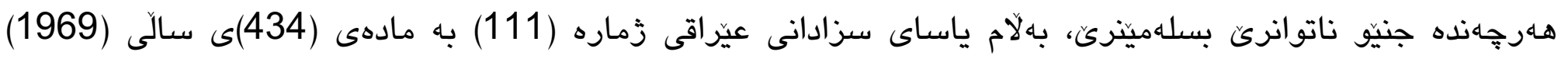

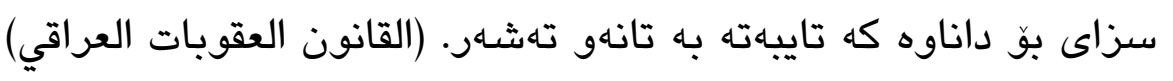

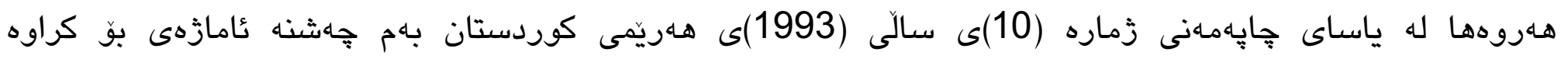

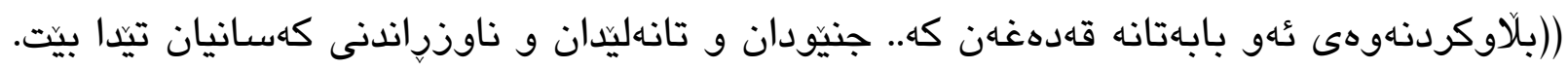

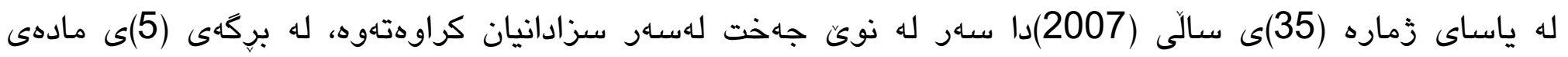

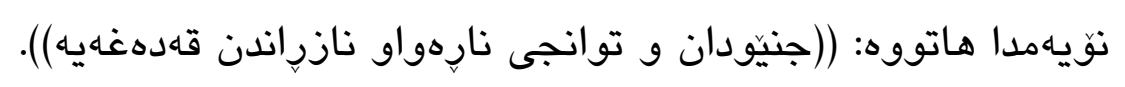




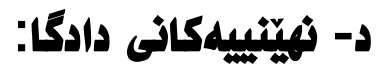

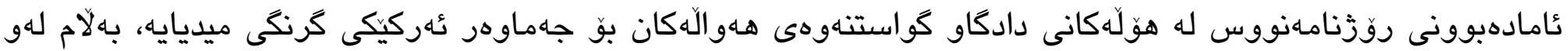

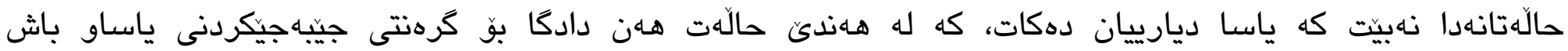

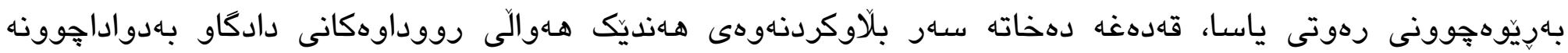

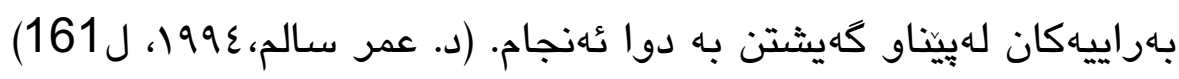

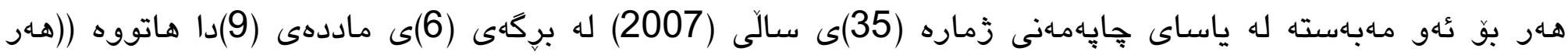

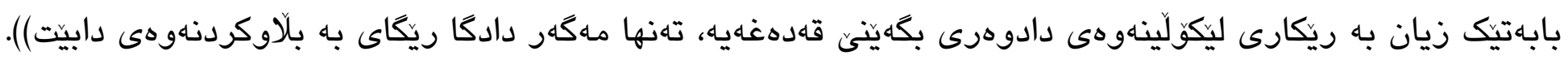

\section{ح- ذئذاذى تايبهث:}

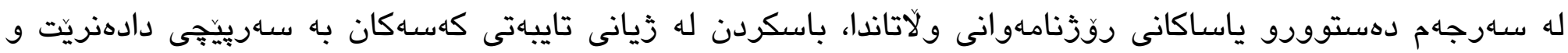

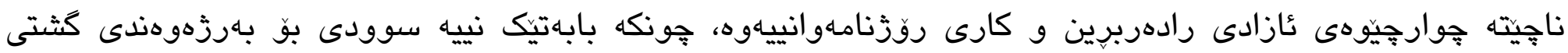

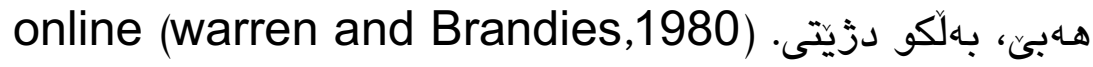

دهكريَ زيانى تايبهت جههند بواريكَ بكريتهوه وهك: مافى تهنيايى، سنوورداركردنى دهستوهردانى زيانى تاك و ريكَّكرتن

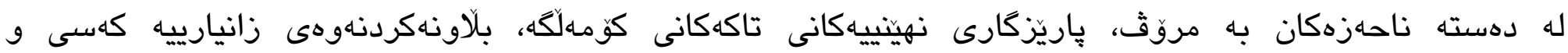

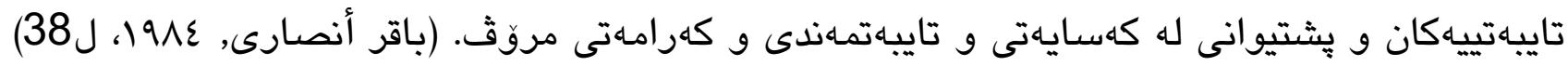

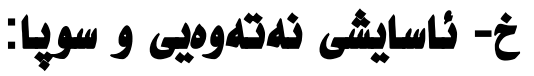

ثاسايش له هـر شوينيكى دنيا ئهو دوخهيه كه مروّق ههست به ئارامى زيان بكات، له زاراوهى ياساييدا به ((ناسايشى

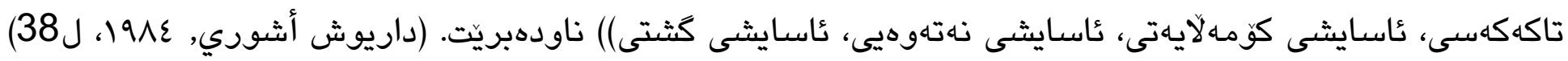

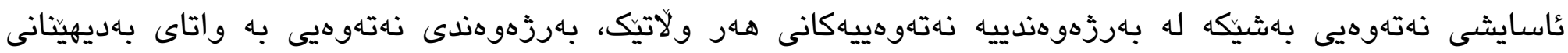

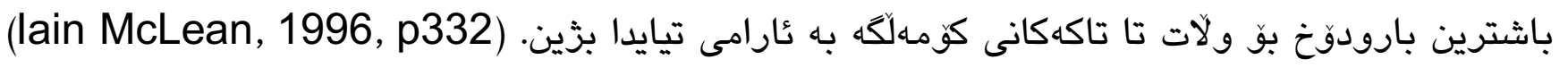

r) جاوديّرى كورث خمايهز:

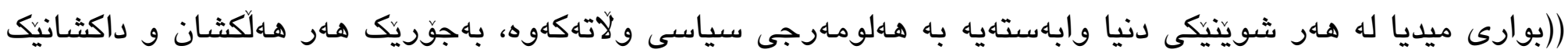

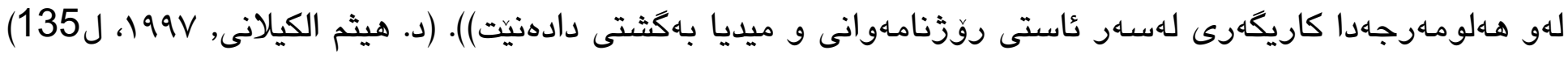


بهكثتى دهتوانرىّ جاوديرّى كورت خايهن وهسف بكركى بهوهى بريتييه له ((جاوديّرى بو ماوهيهكى دياريكراوى كورت

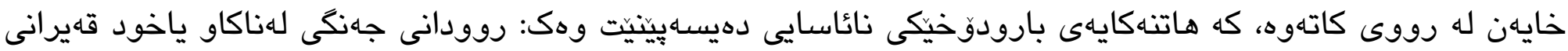

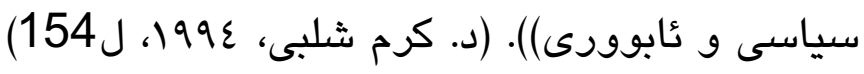

ئهو بارودوخانهى كه جِاوديّرى كورت خايهن تيايدا يِياددهكريتّ وهك:

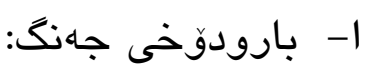

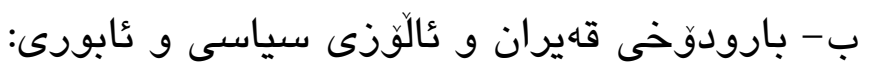
ج- جاوديرى تايبهت:

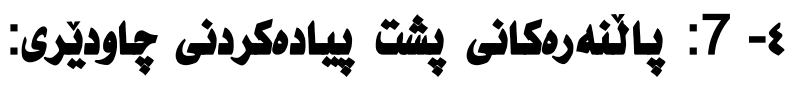

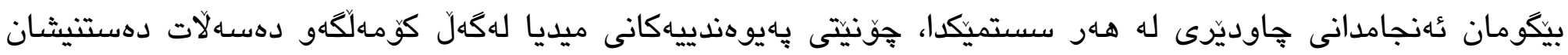

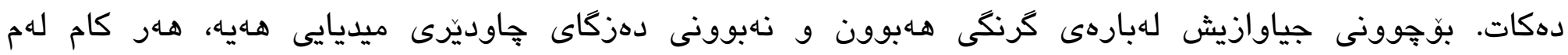

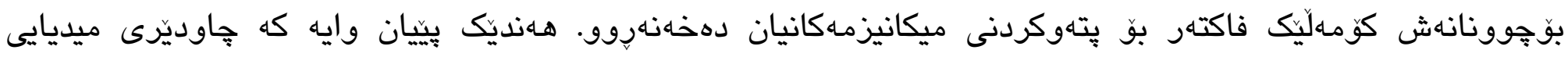

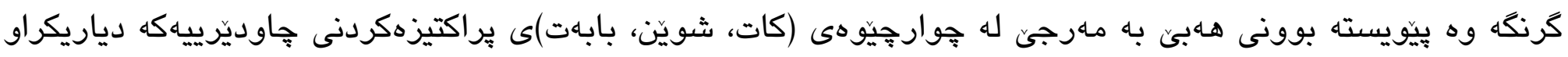

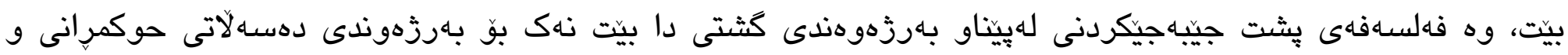

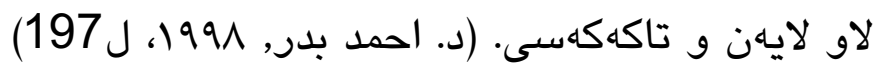

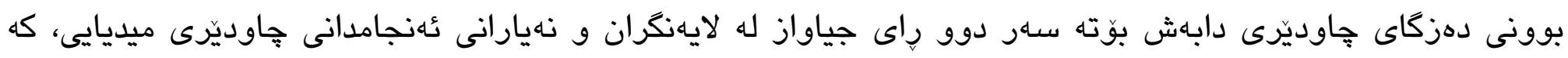

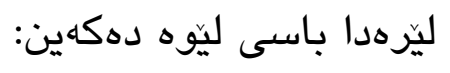

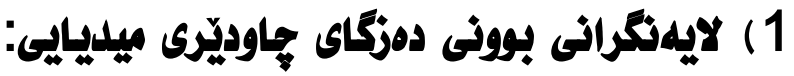

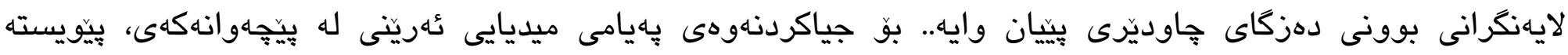

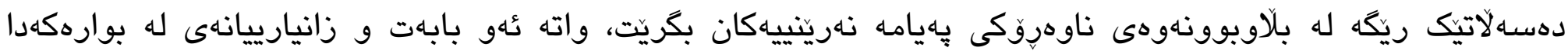

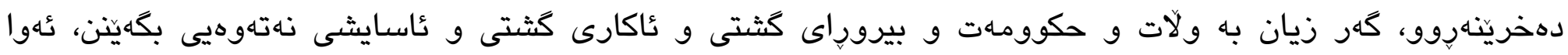

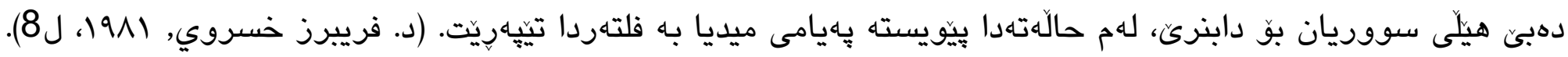

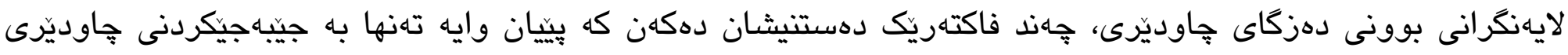

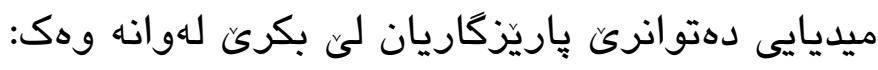




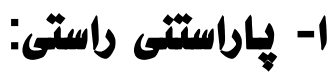

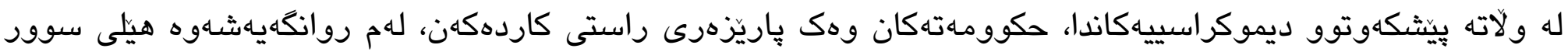

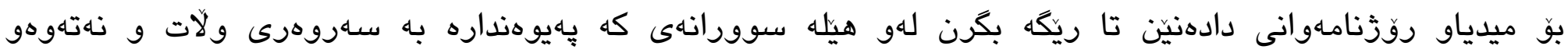

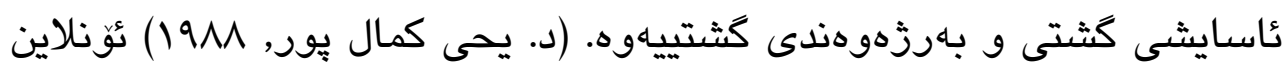

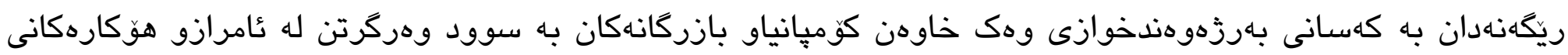

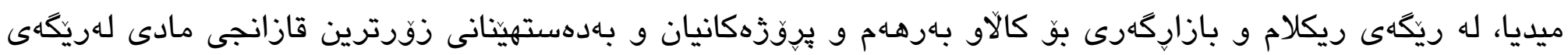
جهاواشهكردنى جهماوهر.

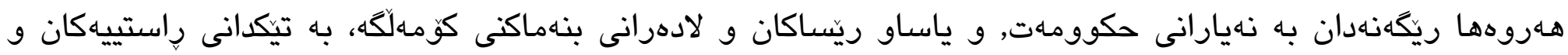

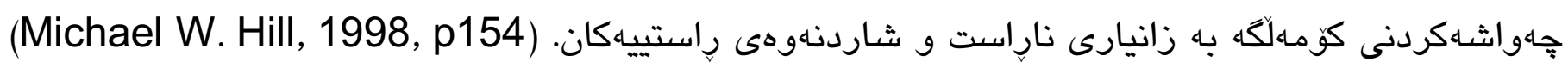

\section{ب- هاراستثى داب و ثلهربتى كومه كلكه:}

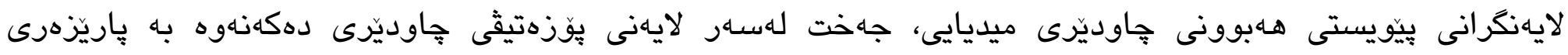

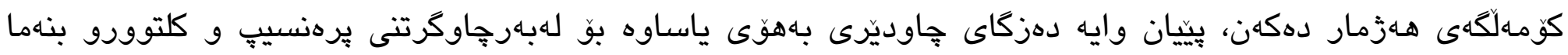

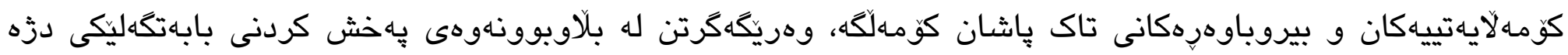

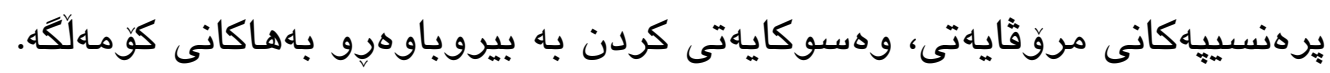

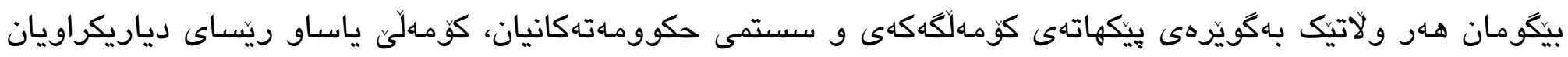

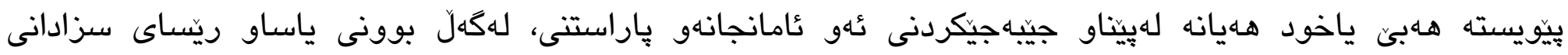

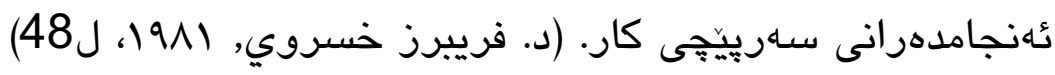

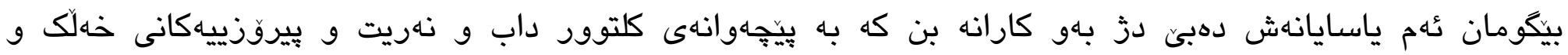

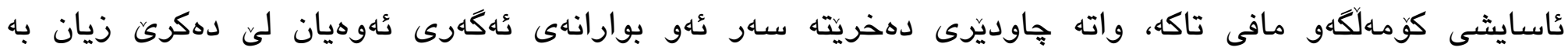

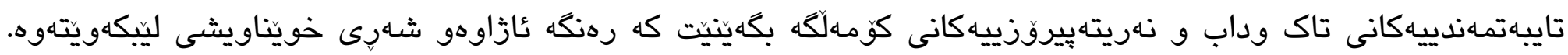

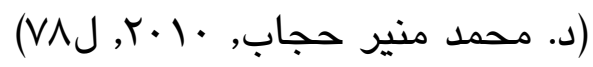

\section{ج- هاراستى ثاسايشى ذلهتهوفيى:}

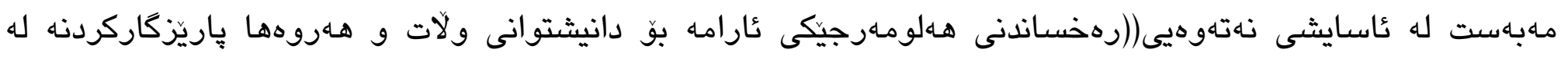

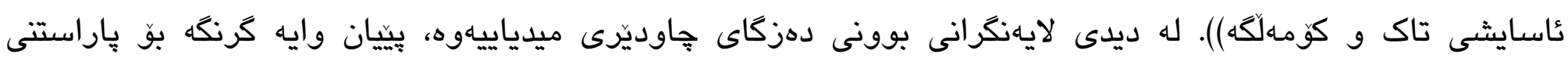

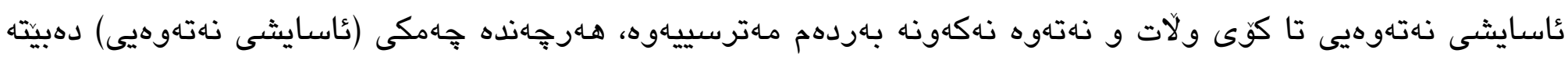




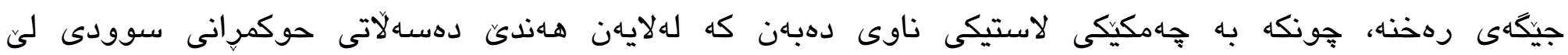

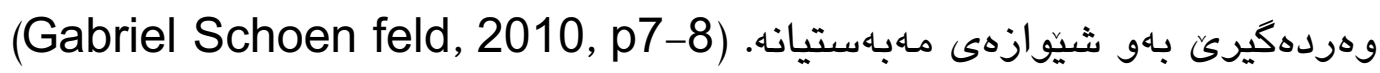

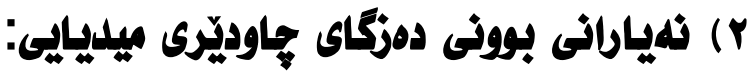

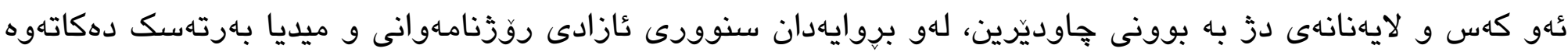

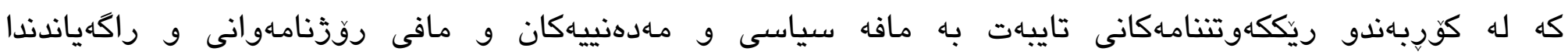

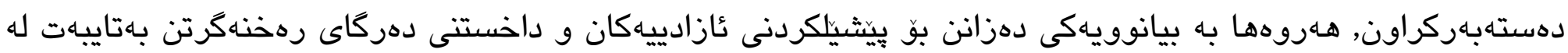

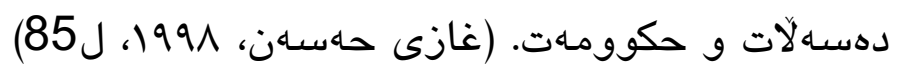

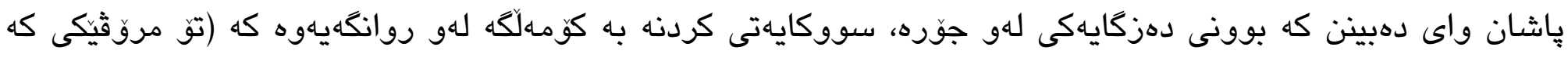

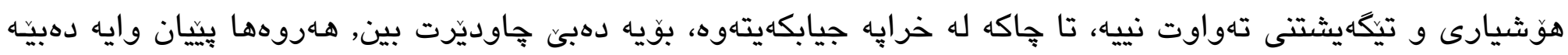
هوّى دروست بوون و بِهرهسندنى جوّره بهدكومانيهكى كَثتى بهرامبهر ميديا، بهتايبهت ميدياى حكوومى لهناو

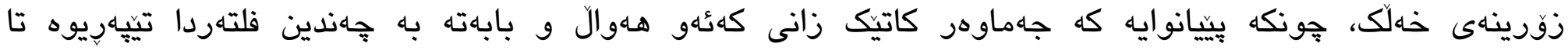

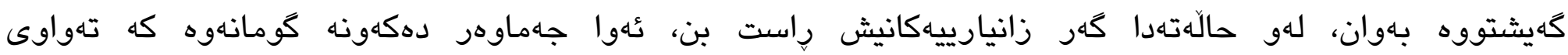

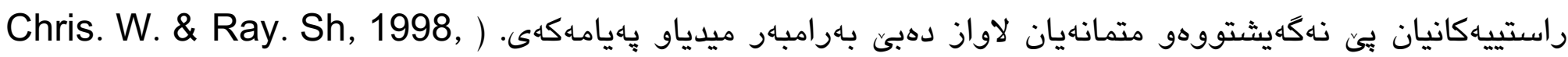




\title{
The role of media censorship, for television channels in Kurdistan Region
}

\section{Gashaw Ali Faraj}

Department of Media, College of Arts, Salahaddin University-Erbil, Kurdistan Region, Iraq. E-mail: gashaw.ali.2017@gmail.com

\section{Saman Jalal Mawlud}

Department of Media, College of Arts, Salahaddin University-Erbil, Kurdistan Region, Iraq. E-mail: dr.samanjalal@gmail.com

\begin{abstract}
:
This research under the title (The role of controlling institutions, for television channels in Kurdistan Region). The main purpose of this research is to show the importance of controlling institutions for the kurdish media movement and find the way and solutions that are important for the content of the media message at television channels not make a censor for the free expression.

In this research the descriptive and survey metod used that are exact with the goals that the researcher wants to get, in the practical side, the spss application used for the meetings and the questionnaire, to get the most data and informations and get the goal of the main problem of the research, that are being because of having no free media controlling institutions or the institutions are weak and there's no law for organize the television channels.

The academic and experts in the media and the journalists from the 4 provinces in Kurdistan Region (Erbil, Sulaimaniya, Duhok, Halabja) are used as a sample and the society of the research.

The research contains six parts, in the first part the frame of the research, second part contains the concepts and defining the media and television theories, third part talks about the levels of the development of local and satellite channels in Kurdistan Region, the fourth part contains the concepts and defines the controling institutions for the media movements, also the controling institutions in the point of the authority and law and executions, the fifth part talks about the controling media institutions in different authority systems, and the last part shows the practical side.

At the end, this research got the consequences that are important for the controling media institutions for the television channels, also all the laws and bases that deal with the media, and shall be Changed, at the same time, write new laws and bases for the media channels and publishment. And decrease the parties's authority for the formal institutions that work in media, and more make sure of the quality of the content and the message of television channels at that institutions in Kurdistan Region.
\end{abstract}

Key Words: Role, Media Censorship, Television Channels, Kurdistan Region. 


\section{سلرجهاومكان:}

امير ناميق عبدالله، ه . .r، راديوو تهلهثزيّنى كهلى كوردستان، له بلاوكراوهكانى مهكتهبى بيرو هوّشيارى (ى. ن. ك).

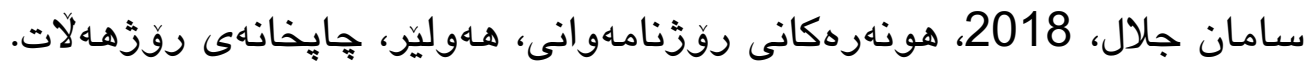

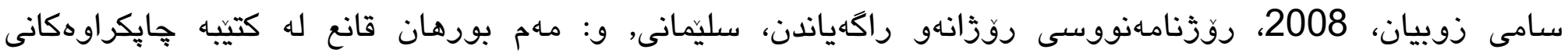
روزَنامهى جְاوديّر.

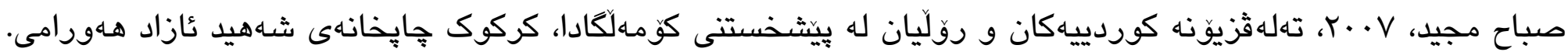

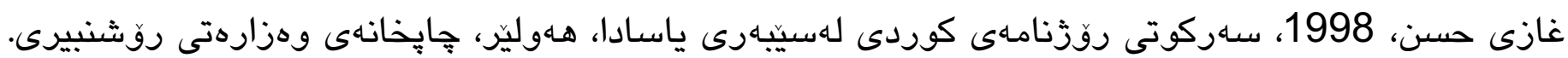

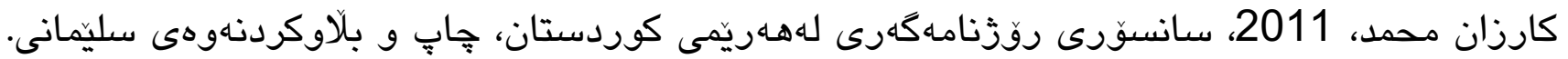

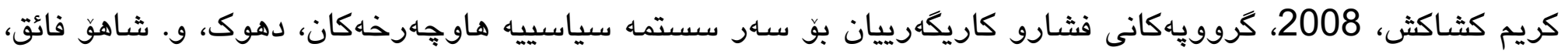
دهزكاى تويّزينهوهو بلاوكردنهوهى موكريان.

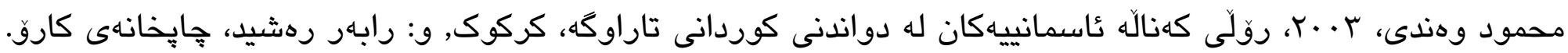

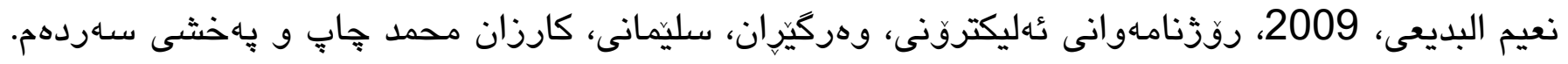

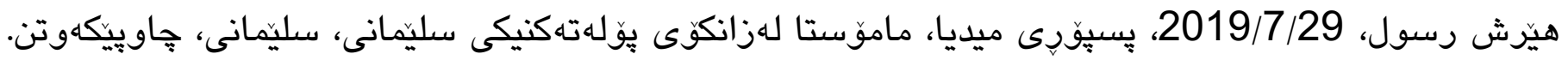
ابراهيم الداقوقى، 1986، قانون الأعلام، مطبعه وزاره الأوقاف والشؤون الدينيه، بغداد. 
احمد بدر، 1998، الأتصال بالجماهير بين الأعلام والتطويع والتنميه،القاهرة,دار البقاء للطباعه والنشر والتوزيع

أسامه صلاح قراعه، الرقابة كوسيله من وسائط الضبط الأجتماعى، بحث متاح على عنوان الأكترونى الأتى: 20/6/2019 ،http://www.manhal.net/articles.php?action=show\&id

$$
\text { اكرم شلبى، معجم المصطلحات الأعلامياء. }
$$

تيسد احمد ابوعرجه، 2006، قضايا ودراسات اعلاميه، دار جرير للنشر والتوزيع.

تيسير أبوعرجه، الصحافه المعاصره، دار الكتاب الجامعى العين دوله الأمارات العربيه.

جيهان احمد رشتى، 1978، الأسس العلمية لنظريات الأعلام، القاهرة، ط2، دار النهضه العربية.

حبيب الراوى، 2001، تاريخ الاذاعه والتلفزيوّن فى العراق، جامعة بغداد

حبيب الهرمزي، 1977، الرقابه على المؤسسات العامة في التشريع العراقى، مطبعه الأوقاف العراق.

حسن سبيلان، 1387، نقش رسانها درمديريت بحران هاى سياسي/ بِذوهشنامه أردستانى شماره (33). حسن عماد مكاوى، وظائف الأتصال والأعلام, القاهرة. حسنين عبدالقادر، 1962، أصول العلاقات العام، القاهره، بدون أسم مطبعه. داريوش أشورى، 1984، دانشنامة سياسى: انتشارات مرواريد، طهران، جاب (11). راسم محمد جمال، 1999, مقدمة فى مناهج البحث فى الدراسات الأرعلامية، كليه الأعلام، جامعة القاهرة. 
سعيد يوسف كلاب، الرقابه الماليه والأداريه ودورها فى عمليه التنميه، ورقه عمل، مقدمة الى مؤتمر التنميه والتطوير قطاع

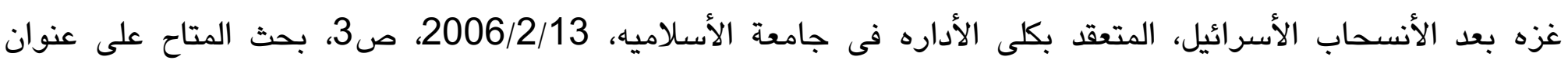

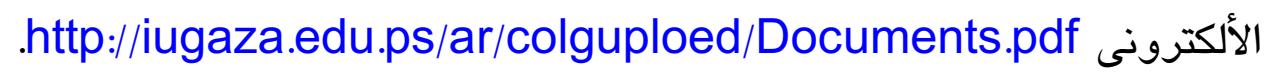

سليمان جازع الشهرى، 2001، مفهوم الرقابه الذاتيه لدى أريع ضحف مصرية، مجلة جامعة الملك سعود، م13، الأداب،

عادل محى الدين، 1987، الرأى العام، بغداد، دار لاشؤون الثقافيه العامة.

عبدالستار جواد، 1995، أتجاهات الأعلام العربى، بغداددراسة في الأعلام الأنجلو - أمريكى، وزاره الثقافه والأعلام، دار الحرية للطباعه. عمر سالم، 1994، نحو قانون جنائى للصحافى، القاهرة. فاروق خالد، 2009، الأعلام الدولى العولمه الجديده، الاردن، دار أسامه للنشر والتوزيع عمان. فريبرز خسروي، 1381/ سانسور د. أينه/ كتابخانهى جمهورى اسلامى ايران. كرم الشلبى، 1994، معجم المصطلحات الأعلاميه، بيروت، انكليزى - عربى/ دار الجيل/ ط2. محمد السيد سرايا، 1986، الأتجاهات الحديثه في مجالات الرقابة، الدار الجامعيه، أسكندريه. محمد بن أبى بكر الرازى، 1981، مختار الصحاح، لبنان, دار الكتاب العربى. محمد منير حجاب، 2010، الأعلام والموضوعيه في القرن الحادى والعشرين،القاهرة, دار الفجر للنشر. مصطفى المصعودى، 1985، النظام الأعلام الجديد، عالم المعرفه. مصطفى مرعى،1980، الصحافه بين السلطه والسلطان، عالم الكتب، القاهره. مولود زايد طيب، 2009، تأثيرات القنوات الفضائيه فى تكوين الشخصيه الطفل، القاهرة, مطبعة وهران. 
يحى كمال يور، 1388، رسانهایى ارتباطى وأزادى د. د. عصر ديجيتال، روزنامة هشري الكتروني: .http://www.hamshahrionline.ir/News/?id

Allen wells, 1975, Mass Communication, A world view, Mayfield Publication company.

Balkin, J, M: 1998, media filters and th V-chip, yale university. Edu.

Buchele Robert. B, 1977, the management of Business public organization, Tokyo, MC Graw- Hill Kogakusha.

Chris Watson \& Roe Shuker, 1998, In the public good? Censorship in New zealand (Palmers ton north, Nz): The Dunmore press.

Gabriel Schoen feld Necessary, 2010, national Security, the media and Rule of law, printed in the united states of America.

Huff Richard, 2007, Tv watch dog is Barking up the wrong tree New york Daily news. From the original on may 18, 2008, Retrieved horembe, 2007.

Lewis Anthony Dexter, 1964, people, Society, and mass communication printed in the united states of America.

Michael. W. Hill, 1998, The Impact of Information on society, An Examination of Its Nature, Value and usage, Publisher: walter de Grwyter \& Co.

Peter Phillips, 2007, censor ship and obscurantism in the American media. 